\title{
A Review of Industrial Crop Yield Performances on Unfavorable Soil Types
}

\author{
Jana Reinhardt ${ }^{\dagger}$, Pia Hilgert ${ }^{\dagger}$ and Moritz Von Cossel $*$ (D) \\ Biobased Resources in the Bioeconomy (340b), Institute of Crop Science, University of Hohenheim, Fruwirthstr. \\ 23, 70599 Stuttgart, Germany; reinhardtja21@gmail.com (J.R.); pia.hilgert@uni-hohenheim.de (P.H.) \\ * Correspondence: mvcossel@gmx.de \\ † Authors contributed equally to this work.
}

check for updates

Citation: Reinhardt, J.; Hilgert, P.;

Von Cossel, M. A Review of Industrial Crop Yield Performances on Unfavorable Soil Types. Agronomy 2021, 11, 2382. https://doi.org/ 10.3390/agronomy11122382

Academic Editor: Carlos Cantero-Martínez

Received: 8 November 2021

Accepted: 20 November 2021

Published: 24 November 2021

Publisher's Note: MDPI stays neutral with regard to jurisdictional claims in published maps and institutional affiliations.

Copyright: (c) 2021 by the authors. Licensee MDPI, Basel, Switzerland. This article is an open access article distributed under the terms and conditions of the Creative Commons Attribution (CC BY) license (https:// creativecommons.org/licenses/by/ $4.0 /)$.

\begin{abstract}
Industrial crop cultivation on marginal agricultural land limits indirect land-use change effects that pose a threat to food security. This review compiles results from 91 published crop-specific field trial datasets spanning 12 relevant industrial crops and discusses their suitability for cultivation on unfavorable soil types (USTs). It was shown that the perennial species Miscanthus (Miscanthus Andersson) and reed canary grass (Phalaris arundinacea L.) performed well on USTs with both high clay and/or high sand contents. Information on stoniness (particles sizes $>2 \mathrm{~mm}$ ), where mentioned, was limited. It was found to have only a small impact on biological yield potential, though it was not possible to assess the impact on mechanization as would be used at a commercial scale. For soils with extreme clay or sand contents, half of the crops showed moderate suitability. The large yield variations within and between crops revealed large knowledge gaps in the combined effects of crop type and agronomy on USTs. Therefore, more field trials are needed on diverse USTs in different climates with better equipment and more consistent measurements to improve the accuracy of potential yield predictions spatially and temporally. Additionally, larger trials are needed to optimize cultivation and harvesting.
\end{abstract}

Keywords: camelina; cardoon; crambe; cup plant; giant reed; hemp; sorghum; switchgrass; poplar; willow

\section{Introduction}

A large proportion of marginal farmlands in Europe are characterized by unfavorable soil types (USTs). However, there are no precise estimates of UST land areas in the literature, as USTs and stoniness are often mentioned in connection with other limiting site factors, such as low rooting depth (LRD) [1,2]. However, LRD and USTs account for nearly half of marginal farmland [1]. This is of great agricultural relevance because the soil type directly influences basic agronomic factors, such as water storage capacity and the plant nutrient availability of the soil. Moreover, the soil type affects the infiltration, runoff, and movement of water in the soil [3]. The grain size fractions of the soil are divided into coarse soil (with equivalent diameters of $>2 \mathrm{~mm}$ ) and fine soil (equivalent diameter of $\leq 2 \mathrm{~mm}$ ) $[3,4]$.

Sandy and loamy-sandy soils have a low water storage capacity [5] and, therefore, reduced soil fertility [3]. For these reasons, there is a loss of yield on sandy soils for food crops. For example, at a site near Jyndevad (Denmark), where the sand content is $88 \%$, maize achieved a 4-year average biomass yield of $10.9 \mathrm{Mg} \mathrm{DM} \mathrm{ha}^{-1}$ [6]. This is considerably lower than yields that can be achieved on non-sandy soils of $20 \mathrm{Mg}^{-1}$ and more [6].

The tiny particles in clay soils both bind water tightly and hinder root penetration, making it harder for plants to establish rapidly [3]. In this study, sites are classified as marginal if they contain soils with the soil type clay (UST-CL) or sand (UST-S) according to the definition of [7] (if soils consist of either $\geq 40 \%$ of the grain size fraction clay (silty clay, loamy clay, clay) or $\geq 70 \%$ of the grain size fraction sand (loamy sand)).

High proportions of coarse fragments or stones $>2 \mathrm{~mm}$ in the soil can also have negative effects on plant growth. A share of more than $15 \%$ coarse soil reduces the water 
holding capacity of soil by at least $40 \%$ and aggravates seasonal droughts in most European climate zones. In addition, a high proportion of coarse fragments, such as stones, can severely restrict the space available for root development, which in turn reduces the absorption of water and nutrients. Moreover, coarse fragments larger than $10 \mathrm{~cm}$ damage tillage equipment, and boulders could be a barrier to tillage in general [3]. For this reason, a site is classified as a marginally unfavorable soil type and stoniness-stones (UST-St) if its soil has a share of $\geq 15 \%$ of coarse soil.

The relevance of agricultural marginality constraints can be expressed by the area of agricultural land affected. The assumed total area of available European marginal cropland that is characterized solely by UST is $<1$ Mha [1], but the actual area is likely much larger, as already noted above. However, this would correspond to tremendous potential for the production of non-food biomass [8], which is urgently required to successfully and promptly manage the transition to a bioeconomy $[9,10]$. Therefore, among many socio-economic challenges [11-15], the success of cultivating industrial crops under UST conditions is critical, with biomass yield being one of the most important components [16, 17]. Furthermore, there is still much uncertainty about the link between USTs and both biomass yield and quality of industrial crops [1,18]. Hence, Gerwin et al. [1] call for this to be investigated more thoroughly in the future, which is also currently being done in projects such as MAGIC [2]. Therefore, this study focuses on the following main research question: How do industrial crops perform in terms of biomass yield on European marginal farmland characterized by UST?

\section{Material and Methods}

In this study, the biomass yield of industrial crops on farmland that is not marginal (e.g., favorable climate and fertile soils) $[19,20]$ was used as a reference for the industrial crops' yield performance on marginal farmland. This was intended to enable a first relevant insight into the future potential of biomass production on marginal farmland. The selection and evaluation of industrial crops were performed as explained in the following sections (Figure 1).

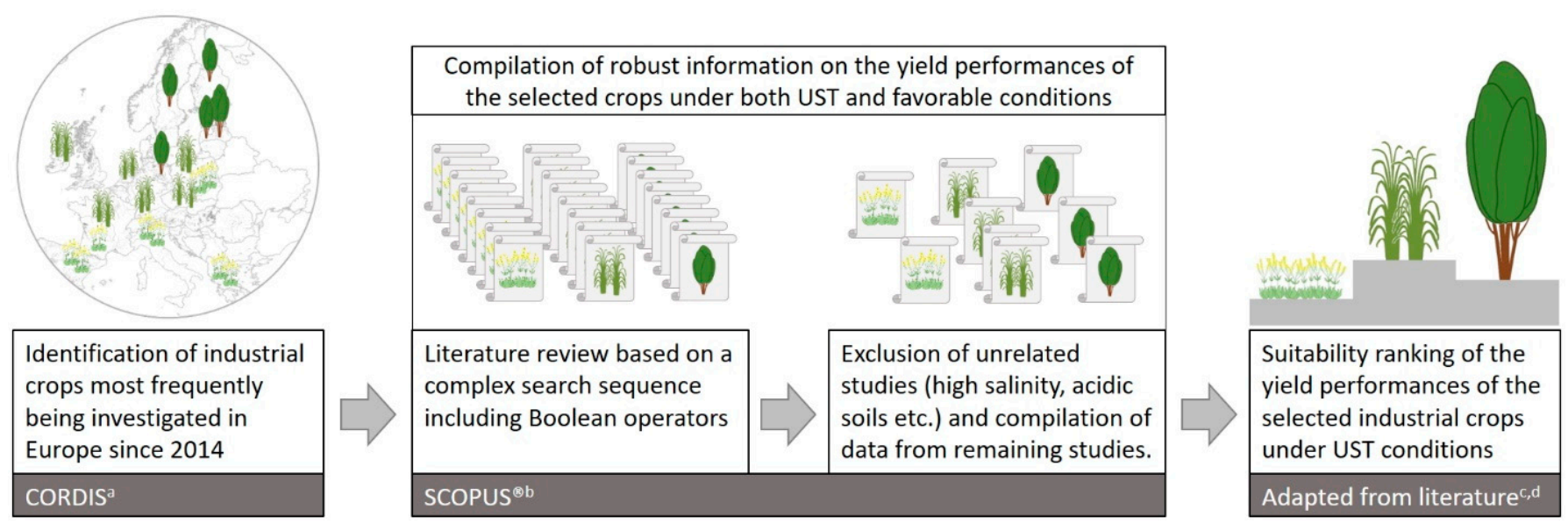

Figure 1. Schematic overview of the methodological approach of this study $\left.\left({ }^{a}[21],{ }^{b}[22],{ }^{c}[8]\right),{ }^{d}[2]\right)$.

\subsection{Identification of Most Relevant Industrial Crops in Europe}

For identifying the most relevant industrial crops in Europe, only those industrial crops were selected that were involved at least four times in one of the EU projects that started or ended in the period 1 January 2014 to 6 December 2019. Using the Community Research and Development Information Service (CORDIS) [21], 24 EU projects were found and considered for this purpose. In this way, twelve industrial crops were found relevant (Table A1), which is mostly in line with the crop selections in other studies $[2,23]$. 


\subsection{Literature Search on the Performance of Industrial Crops under UST Conditions}

An extensive literature search was conducted in the Scopus ${ }^{\circledR}$ database (Elsevier B.V., Amsterdam, The Netherlands) to obtain robust information on the yield performance of the selected industrial crops under both UST and favorable conditions. For this purpose, the advanced search function was used in Scopus ${ }^{\circledR}$ using a complex search sequence including Boolean operators [23]. After documents were identified in which the plant name occurred in the title, abstract, or keywords. For each plant species, both the English trivial name and the botanical name were used in this process. Subsequently, articles containing terms such as "model", "gis", or "gene" were identified and excluded to reduce the search results to original articles with field trial results. In the remaining search results, articles with the marginality factor UST were searched for using common synonyms (adverse soil texture, sandy soil, stoniness, etc.). The studies found were then further selected to determine the location of the trial, any agronomic information, and harvest time and type (whole crop biomass or just seed). Soil properties and weather conditions had to be sufficiently specified to exclude, for example, sites with high salinity, heavy metal contamination, steep slope, or acidic soils. This is because if UST occurs in combination with drought, the effect of drought on yield performance might overshadow the effect of USTs. Therefore, the yieldUST combination has been placed in a broader perspective here and is discussed in more detail when interpreting anomalies in the yield performances of the crops. Non-European sites were excluded only if their climatic conditions were not comparable to any of the European agro-ecological zones.

\subsection{Suitability Ranking}

Based on the yield data for each industrial crop trial and further meta-data in the literature, a classification of the cultivation suitability according to a classification of Ramirez-Almeyda et al. [8] was conducted. If no sites were found that met the criteria described above, the classification was estimated from indirectly related literature. This information is then given in brackets. The classifications are denoted as follows: $4=$ very good, a much higher yield than on favored sites; 3 = good, the yields of the sites were approximately equivalent to the average yields on favored sites; $2=$ average, a lower yield was shown compared to the average yields on favored sites; $1=$ low, much lower yields observed compared to yields on favorable sites. If the plant is classified as 0 , it means that it is considered unsuitable, i.e., it cannot grow on sites with UST [2,8].

\section{Results and Discussion}

According to the methodology described above, 91 crop-specific field trial datasets were found that comply with the threshold values (Table A1). However, since only EU projects were searched for relevant industrial crops in this study (in order to narrow the focus of the study somewhat), it cannot be ruled out that other industrial crops not taken into account might also be relevant for European growing conditions, but have not yet been considered in EU projects. High variations in dry matter yield performances were revealed for most of the crops and each of the three major USTs, sandy, clayey, and stony soil (Figure 2).

Some sites and the respective tests on them, which also meet the criteria of this paper, could not be identified using the methodology described. The reason for this is that in order to classify a site into marginal, certain information about the site is required. However, this information is often missing in papers. The selected sites per plant with the respective yields and information on agricultural marginality constraints can be found in Table A1. In the following Sections 3.1-3.12, the yield performances of the selected industrial crops are presented and discussed as yield per year (biomass, stalk, oil, grain, and ethanol yields). Only the aboveground biomass of the crops is considered. 


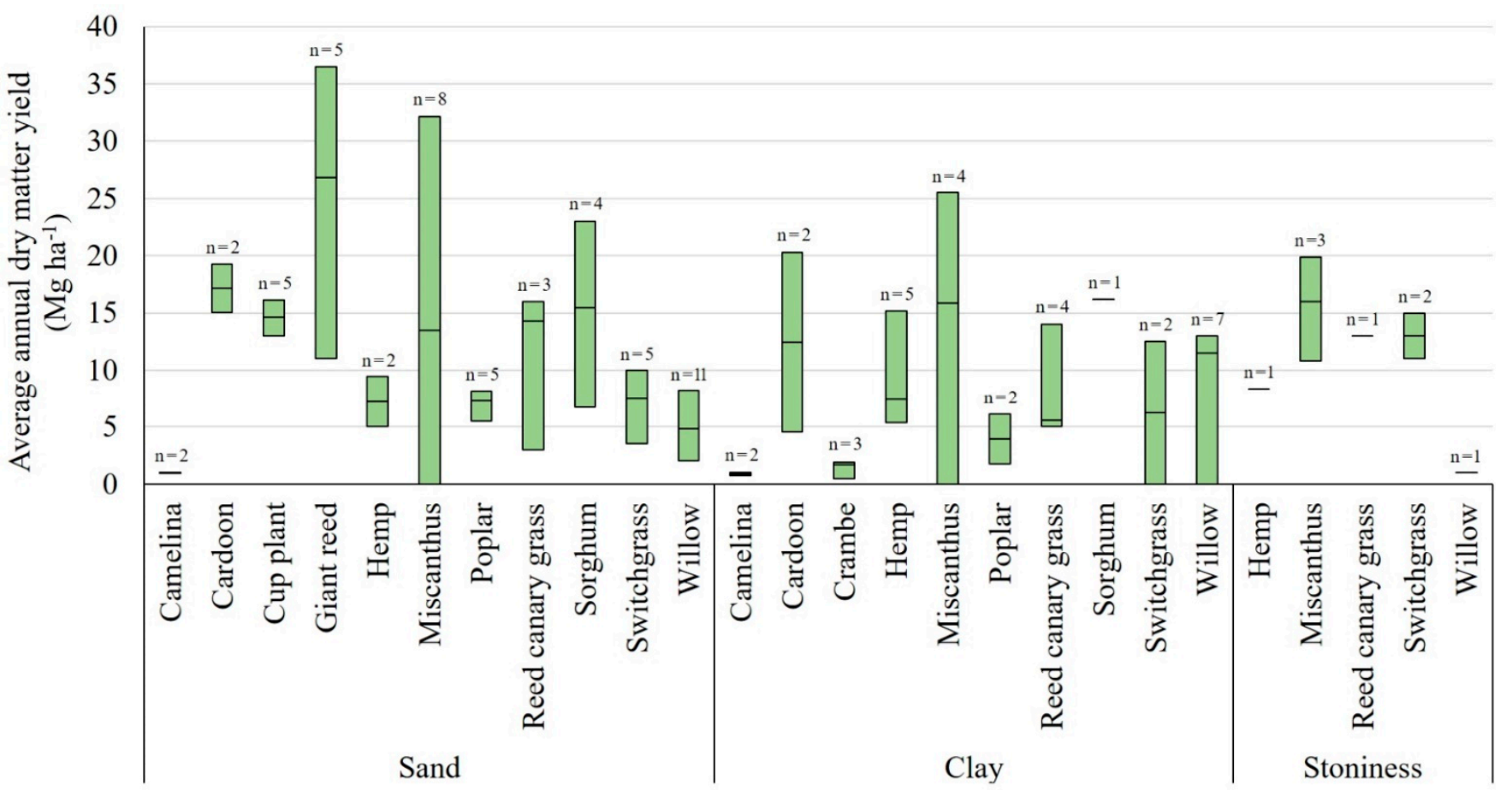

Figure 2. Overview of annual average dry matter yield performances (minimum and maximum values) of the selected industrial crops grown in field trials under unfavorable soil types sandy (Sand), clayey (Clay), and stony soil (Stoniness), finding 3-13 studies per crop (total 91 studies from 16 countries worldwide). The bars show the ranges between the minimum, median, and maximum values per culture, and " $n$ " is the number of values used for the calculation. For Camelina and Crambe, grain yields are shown, for hemp, stem yields are shown, for all other crops, it's the whole aboveground dry matter.

\subsection{Camelina (Camelina sativa L. Crantz)}

On favorable sites, Camelina has an average grain yield of about $1.5 \mathrm{Mg} \mathrm{ha}^{-1}$, usually ranging from 0.9 to $2.2 \mathrm{Mg} \mathrm{ha}^{-1}$ [24]. Under very favorable conditions, the grain yield can be up to $3 \mathrm{Mg} \mathrm{ha}^{-1}$ [25]. The average oil content of the grains is $42 \%$ [26], usually ranging from $35-45 \%$ [24]. The thousand-grain mass is between 0.8 and $1.8 \mathrm{~g}$ [27]. At a favorable location in Austria, an average oil yield of $807 \mathrm{~kg} \mathrm{ha}^{-1}$, a grain yield of $1.9 \mathrm{Mg} \mathrm{ha}^{-1}$, and a thousand grain mass of $1.4 \mathrm{~g}$ was achieved [28]. The results of a trial in Poland on a fertile site showed a grain yield of $1.7 \mathrm{Mg} \mathrm{ha}^{-1}$ to $2.2 \mathrm{Mg} \mathrm{ha}^{-1}$, oil content of $39.3-42.2 \%$, and an oil yield of $690-930 \mathrm{~kg} \mathrm{ha}^{-1}$ [29]. The amount of the yield is mainly influenced by the environment and, to a lesser extent, by the genotype [30].

Two locations, each meeting the criteria UST-clay (El centro and West Side) and UST-sand (Güterfelde and Wilmersdorf), were found (Tables 1 and A1).

Table 1. Grain yields per year of Camelina (Camelina sativa L. Crantz) under unfavorable soil types (USTs) conditions $(\mathrm{S}=$ sand, $\mathrm{Cl}=$ clay $)$.

\begin{tabular}{ccccc}
\hline Marginality Factor & Grain Yield $\left[\mathbf{M g ~ h a}^{-\mathbf{1}}\right.$ ] & Place & Country & Source \\
\hline UST-S & & Summer-annual Camelina & & \\
UST-S & 0.91 & Güterfelde & Germany & [31] \\
& 1.01 & Wilmersdorf & Germany & \\
UST-Cl & & Winter-annual Camelina & USA & [33] \\
UST-Cl & 0.73 & El centro & USA & [33] \\
\hline
\end{tabular}

Summer Camelina was grown on the Güterfelde and Wilmersdorf sites and winter Camelina on the El centro and West Side sites. The grain yields on all four sites are lower 
(Table 1) compared to the stated average grain yield of $1.5 \mathrm{Mg} \mathrm{ha}^{-1}$; however, the yields of West Side, Güterfelde, and Wilmersdorf are in the yield range on favorable sites [24]. The oil content in Güterfelde was $40 \%$, which corresponds to the figures in Panacea [26]. The oil yield of $364 \mathrm{~kg} \mathrm{ha}^{-1}$ at this site is lower than the oil yield of $807 \mathrm{~kg} \mathrm{ha}^{-1}$ found by Vollmann et al. [28]. In Güterfelde and Wilmersdorf, the soil type is loamy sand. The grain yield on the site Güterfelde comes from a trial with different fertilization variants. The stated yield was achieved without fertilization. It was found that the variant without fertilization leads to a nitrogen deficiency on this site, which is why the leaves become small, pale yellow-green, and ripen prematurely [31]. A higher fertilization $\left(120 \mathrm{~N} \mathrm{~kg} \mathrm{ha}^{-1}\right)$ level led to a higher grain yield of $1.8 \mathrm{Mg} \mathrm{ha}^{-1}$. The oil content decreased significantly with the increase of the nitrogen fertilizer to 38\% [31]. In the trial, years 2003 and 2004, Wilmersdorf was affected by a severe drought in spring, and in 2005, heavy rainfall occurred in May [32]. The yield was probably, therefore, lower compared to the average yield on favored sites [24]. According to the classification in Von Cossel et al. [2,34], Camelina is well suited for cultivation on sandy soils. This is also confirmed by the results found under sufficient nitrogen and water supply.

In El centro, the grain yield of $0.73 \mathrm{Mg} \mathrm{ha}^{-1}$ was lower than the grain yield on the West Side with $1.02 \mathrm{Mg} \mathrm{ha}^{-1}$. This difference in grain yield can be explained by the fact that the clay content of $57.5 \%$ at $\mathrm{El}$ centro is higher than that of $45.4 \%$ at West Side.

Consequently, Camelina can be cultivated on a wide variety of soils, with the exception of heavy clay soils $[27,29,35,36]$. With $57.5 \%$ clay content, the El centro soil is still clay soil according to the FAO classification of soil types but close to the border with heavy clay soil, which may explain the lower yield. According to the classification in Von Cossel et al. [2,34], Camelina has a good cultivation tendency for clay soils and a medium cultivation tendency on heavy clay soils. However, in view of the above results, the suitability of Camelina on UST-CL is moderate to good.

\subsection{Cardoon (Cynara cardunculus L.)}

In Europe, cardoon achieves an above-ground biomass yield of $10-30 \mathrm{Mg} \mathrm{ha}^{-1} \mathrm{DM}$ and a grain yield of $0.6-4.3 \mathrm{Mg} \mathrm{ha}^{-1}$ under different irrigation and fertilization options [37-41]. On favorable sites, cardoon achieves an average aboveground DM yield of $20 \mathrm{Mg}^{-1}$ DM [42]. This is also shown by Fernández et al. [38], who indicate that cardoon produced a DM yield of $24.2 \mathrm{Mg} \mathrm{ha}^{-1}$, averaged over four different favored sites in Europe. A field trial over three years in Catania, Italy, on a favored site, investigated the yield of different genotypes. A maximum yield of $36.2 \mathrm{Mg} \mathrm{ha}^{-1}$ aboveground DM biomass and $2.8 \mathrm{Mg} \mathrm{ha}^{-1}$ grain yield was achieved. On average, over all of the test years and genotypes, $20.6 \mathrm{Mg} \mathrm{ha}^{-1}$ above-ground DM biomass, $1.37 \mathrm{Mg} \mathrm{ha}^{-1}$ grain yield, and a thousand-grain mass of $29.3 \mathrm{~g}$ were determined [43]. In an experiment by Angelini et al. [44], cardoon was grown for eleven years on a favored site without irrigation. An average yield of 12.6 $\mathrm{Mg} \mathrm{ha}^{-1} \mathrm{DM}$ was achieved over all of the eleven growing years. The yield results under UST conditions are only from trials determined from the 1st to 3rd year of cultivation. In comparison, Angelini et al. [44] reported an average above-ground DM yield of cardoon of $19.4 \mathrm{Mg} \mathrm{ha}^{-1}$ in the 2 nd to 4 th year.

Three different locations were found for this agricultural marginality constraint (Tables 2 and A1).

Table 2. Grain and biomass yields per year of cardoon (Cynara cardunculus L.) under varying unfavorable soil types (USTs) (DR = drought, $\mathrm{S}=$ sand, $\mathrm{CL}=$ clay, $\mathrm{SSL}=$ steep slope, $\mathrm{DM}=$ dry matter $)$.

\begin{tabular}{|c|c|c|c|c|c|}
\hline Marginality Factor & $\begin{array}{l}\text { DM Yield } \\
{\left[\mathrm{Mg} \mathrm{ha}^{-1}\right]}\end{array}$ & Grain Yield [Mg ha $\left.{ }^{-1}\right]$ & Place & Country & Source \\
\hline DR; UST-S & 15.1 & & Enna & Italy & [45] \\
\hline UST-S & 19.3 & & Enna & Italy & [45] \\
\hline UST-CL & 20.3 & 1.2 & Catania & Italy & [46] \\
\hline SSL, UST-CL & 4.6 & & Daganzo & Spain & [47] \\
\hline
\end{tabular}


The Enna site was classified as marginal due to its sandy soil. The Catania site is marginal due to a clay content of $45 \%$ in the soil, and the Daganzo site is also marginal due to its clay soil. The Enna site achieved an average yield of $19.3 \mathrm{Mg} \mathrm{ha}^{-1} \mathrm{DM}$ in the first three years of cultivation (first year 26.1, second year 22.5, and third year 9.2 $\mathrm{Mg} \mathrm{ha}^{-1}$ ) $[38,43]$. The Catania location also produced a yield comparable to a favorable location with 20.3 $\mathrm{Mg} \mathrm{ha}^{-1} \mathrm{DM}$ and 1.2 $\mathrm{Mg} \mathrm{ha}^{-1}$ grain yield. Five different genotypes were grown on fields in Catania, with globe artichoke $\times$ wild cardoon in the second year with a DM yield of $27.6 \mathrm{Mg} \mathrm{ha}^{-1}$ and globe artichoke $\times$ cultivated cardoon in the third year with $27.7 \mathrm{Mg} \mathrm{ha}^{-1}$. Only the Daganzo site had a much lower DM yield of $4.6 \mathrm{Mg} \mathrm{ha}^{-1}$. This was probably due to the negative effects of the combination of steep slope (SSL) and UST-CL. UST-CL soils have a low water infiltration capacity. On sloping terrain, low infiltration leads to rainwater run-off, which in turn leads to reduced soil moisture and thus increases the risk of drought [5].

After a classification in Von Cossel et al. [2,34], cardoon has: medium cultivation suitability for sandy soils as well as for clay soils, very good cultivation suitability for silt soils, and is unsuitable for heavy clay soils. Ţîţei [48] reports that the cultivation of cardoon on clay and heavy clay soils is not recommended. In contrast, the yield on the Catania site indicates that cardoon is relatively well-suited for cultivation on clay soils. The yield of cardoon on the Enna site additionally contradicts the assessment in Von Cossel et al. [2,34] and shows a good suitability for cultivation on sandy soils.

\subsection{Crambe (Crambe abyssinica Hochst. Ex R.E.Fr.)}

Only two sites were found for the plant Crambe, and these were found for the agricultural marginality constraint UST-CL (Tables 3 and A1). The grain yield of Crambe can range from $0.2-3.2 \mathrm{Mg} \mathrm{ha}^{-1}$, depending on soil, climate conditions, and crop management [49].

At favorable locations in Poland, Crambe achieved a grain yield of $1.2-3.2 \mathrm{Mg} \mathrm{ha}^{-1}$ [50]. In Legnaro in northern Italy, Crambe achieved a grain yield of $2.7 \mathrm{Mg} \mathrm{ha}^{-1}$, an oil yield of $837 \mathrm{~kg} \mathrm{ha}^{-1}$, and a thousand-grain mass of $6.12 \mathrm{~g}$ [51]. In Europe, Crambe achieved an average grain yield of $2.4 \mathrm{Mg} \mathrm{ha}^{-1}$ and an average oil yield of $846 \mathrm{~kg} \mathrm{ha}^{-1}$ [52]. The average oil content of the grains was 38\% [53] and the thousand-grain mass was 6-10 g [52].

Table 3. Grain and oil yields per year of Crambe (Crambe abyssinica Hochst. Ex R.E.Fr.) on marginal agricultural lands with unfavorable soil types (UST) (CL = clay).

\begin{tabular}{cccccc}
\hline Marginality Factor & Grain Yield [Mg ha $\left.{ }^{-\mathbf{1}}\right]$ & $\begin{array}{c}\text { Oil Yield } \\
{\left[\mathbf{k g ~ h a}^{-\mathbf{1}}\right]}\end{array}$ & Place & Country & Source \\
\hline UST-CL & 0.49 & 104 & Cascavel-Paraná & Brazil & {$[54]$} \\
UST-CL & 1.7 & & Cascavel-Paraná & Brazil & {$[55]$} \\
\hline
\end{tabular}

The site in Rosa et al. [54] was classified as marginal, as it is an Oxisol soil with a high clay content. In Viana et al. [55], the soil was described as Red Latosol with a high clay content. The clay content in Rosa et al. [54] was much lower than in Viana et al. [55] and on favored sites $[52,56,57]$. The oil yield was also significantly lower than the oil yield on favored sites [51,52]. The grain yield in Viana et al. [55] was within the grain yield range of favored locations in Poland [57] but was almost $1 \mathrm{Mg} \mathrm{ha}^{-1}$ lower compared to the average European grain yield of $2.4 \mathrm{Mg} \mathrm{ha}^{-1}$ [52]. In Zanetti et al. [51], a field trial in Pozzallo Italy with winter-annual Crambe was described. With a clay content of 38\%, this site does not meet the described criteria of a marginal agricultural land, but has a high clay content. With a grain yield of $1.9 \mathrm{Mg} \mathrm{ha}^{-1}$, it is comparable with favorable sites in Poland [50]. However, it is below the average grain yield of Crambe in Europe [52]. The thousand-grain weight of $5.8 \mathrm{~g}$ is below that of favored sites (even if only slightly), as is the oil yield of $500 \mathrm{~kg} \mathrm{ha}^{-1}$ [51,52]. According to Zhu [49], Crambe needs fertile soils with a moderately coarse to fine texture to achieve high yields. According to Von Cossel et al. [2,34], Crambe is very suitable for clay and sandy soils. In contrast, the results described above show 
a rather mediocre suitability of Crambe for cultivation on UST-CL, most likely due to a combination of limitations in the field trials. Furthermore, Crambe can only grow poorly on stony soils [52], with the main limitation being low fertility, and higher susceptibility to drought events may further reduce the suitability of stony soils for Crambe.

\subsection{Cup Plant (Silphium perfoliatum L.)}

Under good growing conditions, cup plant DM yields from the 2nd year of cultivation onwards are 11-22 $\mathrm{Mg} \mathrm{ha}^{-1}$ [58-60]. Usually, the DM yield is about $15 \mathrm{Mg} \mathrm{ha}^{-1}$ [59]. In a study by the Chamber of Agriculture of Lower Saxony, a DM yield of $15.8 \mathrm{Mg} \mathrm{ha}^{-1}$ was determined for cup plants in the 3rd year of harvest (average over three trial locations) [61].

Five locations were found for the agricultural marginality constraint UST-S (Tables 4 and A1).

Table 4. Annual biomass yields of cup plant (Silphium perfoliatum L.) grown under unfavorable soil type (UST) conditions ( $\mathrm{S}=$ sand, $\mathrm{DM}=$ dry matter).

\begin{tabular}{|c|c|c|c|c|}
\hline Marginality Constraint & $\begin{array}{l}\text { DM Yield } \\
{\left[\mathrm{Mg} \mathrm{ha}^{-1}\right]}\end{array}$ & Place & Country & Source \\
\hline UST-S & 14.6 & Werlte & Germany & {$[62]$} \\
\hline UST-S & 13.0 & $\begin{array}{c}\text { Danube- } \\
\text { Gravel plain }\end{array}$ & Germany & {$[60]$} \\
\hline UST-S & 13.0 & $\begin{array}{c}\text { Altitude } \\
\text { Bavarian Forest }\end{array}$ & Germany & {$[60]$} \\
\hline UST-S & 14.6 & Lipnik & Poland & [63] \\
\hline UST-S & 16.1 & Brunswick & Germany & [64] \\
\hline
\end{tabular}

The determined yields were between 13 and 16.1 $\mathrm{Mg} \mathrm{DM} \mathrm{ha}^{-1}$ for the 2 nd year of cultivation. This corresponds to the yields on favorable sites [59]. At the Lipnik site, a high yield of $19.8 \mathrm{Mg} \mathrm{DM} \mathrm{ha}^{-1}$ was achieved in the $3 \mathrm{rd}$ year of cultivation. The review of Gansberger et al. [59] concludes that the soil type has no clear influence on the yield. The cup plant is tolerant to different soil types and has, therefore, a good cultivation suitability for sites with UST-S. However, maximum yields can only be achieved on nutrient-rich soils with good water availability [58-60].

\subsection{Giant Reed (Arundo donax L.)}

It was reported that $50 \%$ of all DM yield data of giant reed are in the range of 25-40 $\mathrm{Mg} \mathrm{ha}^{-1}$ [65] (Figure 2). Under favorable growing conditions, giant reed shows very high yields of $33.8 \mathrm{Mg} \mathrm{ha}^{-1}$ [66] to $37.7 \mathrm{Mg} \mathrm{ha}^{-1}$ [67]. This is in line with Pilu et al. [68], who report DM yields of $36-55 \mathrm{Mg} \mathrm{ha}^{-1}$. Four marginal agricultural lands with the factor UST-S were found for giant reed (Tables 5 and A1).

Table 5. Annual biomass yields of giant reed (Arundo donax L.) on marginal agricultural lands prone to unfavorable soil types (USTs) (DR = drought, $\mathrm{S}=$ sand, $\mathrm{DM}=$ dry matter).

\begin{tabular}{cccccc}
\hline $\begin{array}{c}\text { Marginality } \\
\text { Constraint }\end{array}$ & $\begin{array}{c}\text { Year of } \\
\text { Cultivation }\end{array}$ & $\begin{array}{c}\text { DM Yield } \\
{\left[\mathbf{M g ~ h a}^{-\mathbf{1}}\right]}\end{array}$ & Place & Country & Source \\
\hline UST-S; & $2 .-3$. & 26.8 & Enna & Italy & {$[45]$} \\
DR & $2 .-3$. & 36.5 & Enna & Italy & {$[45]$} \\
UST-S & 2. & 29.1 & Citra & USA & {$[69]$} \\
UST-S & $2 .-3$. & 17.0 & San Piero a Grado & Italy & {$[70]$} \\
UST-S & $1 .-8$. & 11.0 & Casale Monferrato & Italy & {$[71]$} \\
UST-S & & & & &
\end{tabular}

Compared to the other sites with this factor, the DM yield was lowest in Casale Monterrato with $11 \mathrm{Mg} \mathrm{ha}^{-1}$. This site was the only one not fertilized. Furthermore, the sand content of this soil is very high at $90 \%$ [71]. This is probably why the yield was lower. 
At the San Piero a Grade site, the sand content is 77.8\%, and the conditions in summer 2011 were extremely dry. Giant reed was not irrigated in this trial, unlike the other sites with this factor. The high sand content of the soil reduces its ability to retain water, which has an effect on plant development, especially in dry summers when precipitation is low [70]. Probably for this reason, the DM yield of giant reed was lower with $17 \mathrm{Mg} \mathrm{ha}^{-1}$ compared to the Citra and Enna sites and compared to favorable sites [67,68]. At $29.1 \mathrm{Mg} \mathrm{ha}^{-1}$ $\mathrm{DM}$ and $26.8 \mathrm{Mg} \mathrm{ha}^{-1} \mathrm{DM}$, respectively, the yield at the Citra and Enna sites was only slightly below that of favored sites [66-68]. At the Enna site, the DM yield with sufficient irrigation was $36.5 \mathrm{Mg} \mathrm{ha}^{-1}$, which is very similar to the yield of Angelini et al. [67] with $37.7 \mathrm{Mg} \mathrm{ha}{ }^{-1}$ on a clay soil, i.e., a favored site. With higher fertilization and sufficient irrigation, a significantly higher DM yield of $42 \mathrm{Mg} \mathrm{ha}^{-1}$ can be achieved on the Enna site compared to the experimental variant with low fertilization and little irrigation [45].

Giant reed can grow in all soil types, from clay to sandy, and also on soils with a high stone content [72]. However, the best conditions are sandy and peaty soils with a sufficiently high groundwater level [73]. According to the division made by von Cossel et al. [2,34], giant reed is well suited for clay soils, medium for sand, and very well-suited to clay soils. Parenti et al. [74] classify the suitability for cultivation as follows: very good for a sandy or loamy sandy soil, medium for a soil with more than $50 \%$ clay content, and good for a stony soil. The results confirm that giant reed is well suited for cultivation on sandy soils, provided that sufficient precipitation falls or that irrigation is applied.

\subsection{Hemp (Cannabis sativa L.)}

On favorable sites, fiber hemp achieves an average stalk yield of $10 \mathrm{Mg} \mathrm{ha}^{-1} \mathrm{DM}$ [75]. Struik et al. [76] investigated five different varieties of hemp grown for fiber on three favored sites in Europe (Italy, The United Kingdom, and The Netherlands) over three years with different fertilization and plant density variants. A maximum above-ground biomass yield of $22.5 \mathrm{Mg} \mathrm{ha}^{-1} \mathrm{DM}$ and a stalk yield of $18.5 \mathrm{Mg} \mathrm{ha}^{-1} \mathrm{DM}$ were achieved. The average aboveground DM biomass yield over all of the locations, years, varieties, and trial variants was $14 \mathrm{Mg} \mathrm{ha}^{-1}$ with a stalk DM yield of $11 \mathrm{Mg} \mathrm{ha}^{-1}$. Furthermore, on a sandy loamy soil in Foulum, Denmark, an above-ground biomass yield of $13-15 \mathrm{Mg} \mathrm{ha}^{-1} \mathrm{DM}$ was achieved [6]. For industrial processing of the fibers, the optimum stem length was 200-250 cm [75]. Six different locations were found for UST (Tables 6 and A1).

Table 6. Annual stalk and whole above-ground biomass yields of hemp (Cannabis sativa L.) on various types of unfavorable soil types (USTs) $(\mathrm{S}=$ sand, $\mathrm{ST}=$ stoniness, $\mathrm{CL}=$ clay, $\mathrm{DM}=$ dry matter).

\begin{tabular}{|c|c|c|c|c|c|c|}
\hline Marginality Factor & DM Stem Yield [Mg ha $\left.{ }^{-1}\right]$ & $\begin{array}{l}\text { DM Yield } \\
{\left[\mathrm{Mg} \mathrm{ha}^{-1}\right]}\end{array}$ & $\begin{array}{c}\text { Plant Height } \\
{[\mathrm{cm}]}\end{array}$ & Place & Country & Source \\
\hline UST-S & & $\begin{array}{c}5 \\
\text { Monoecious }\end{array}$ & & Jyndevad & Denmark & [6] \\
\hline UST-CL & 7.1 & & 182 & $\begin{array}{l}\text { Jokioinen } \\
\text { (Tu) }\end{array}$ & Finland & [77] \\
\hline UST-CL & 5.4 & & 130 & $\begin{array}{l}\text { Jokioinen } \\
\text { (Tt) }\end{array}$ & Finland & [78] \\
\hline UST-ST & 8.3 & & & Michamps & Belgium & [79] \\
\hline UST-S & & 9.4 & & $\begin{array}{l}\text { Potsdam- } \\
\text { Bornim }\end{array}$ & Germany & [80] \\
\hline & & Dioecious & & & & \\
\hline UST-CL & 8.0 & & 208 & Jokioinen $(\mathrm{Tu})$ & Finland & [77] \\
\hline UST-CL & 7.4 & & 183 & Jokioinen $(\mathrm{Tt})$ & Finland & [78] \\
\hline UST-CL & 15.2 & 17.8 & 277 & Randwijk & Netherlands & [81] \\
\hline
\end{tabular}

The Michamps site was classified as marginal, as it has very stony soil. Five different monoecious varieties were cultivated on it, which had an average yield of $8.3 \mathrm{Mg} \mathrm{ha}^{-1}$ $\mathrm{DM}$ and a grain yield of $0.26 \mathrm{Mg} \mathrm{ha}^{-1}$ over one year. The variety Epsilon 68 achieved the highest yield on this site with $10.5 \mathrm{Mg} \mathrm{ha}^{-1} \mathrm{DM}$ [79]. The stem yield was somewhat 
lower compared to yields on favored sites, although for the variety Epsilon 68, only very little [76]. The suitability of growing hemp on stony soil is therefore good.

For the unfavorable soil type sand, the sites Potsdam-Bormin (loamy sand) and Jynde$\operatorname{vad}$ (sandy soil) were found. The soil of Jyndevad has a very high sand content $(88 \%)$ and achieved an above-ground biomass yield of $5 \mathrm{Mg} \mathrm{ha}^{-1} \mathrm{DM}$. This is very bad in comparison to the favored site Foulum, which was also investigated by Manevski et al. [6] and achieved an above-ground biomass yield of $13-15 \mathrm{Mg}^{-1} \mathrm{DM}$. Jyndevad was described in Manevski et al. [6] and classified as unsuitable for hemp cultivation, as only a low yield was achieved. The monoecious varieties Fedora 19 and Fedrina 74 were grown at the Potsdam-Bornim site. Under the fertilization variant $0 \mathrm{~N} \mathrm{~kg} \mathrm{ha}^{-1}$, an average above-ground biomass yield of $9.4 \mathrm{Mg} \mathrm{ha}^{-1} \mathrm{DM}$ was achieved [80]. This is also lower than on a favored site [6,76]. With a fertilization of $150 \mathrm{~N} \mathrm{~kg} \mathrm{ha}^{-1}$, the yield increased to $11.8 \mathrm{Mg} \mathrm{ha}^{-1} \mathrm{DM}$. Overall, the yields on sites with UST-S show a medium suitability for cultivation, but hemp is only slightly suitable for cultivation on soils with very high sand content.

The Randwijk and Jokioninen sites were classified as marginal agricultural lands due to the heavy clay soil, and the Jokioninen site due to its silty clay soil. In addition to this agricultural marginality constraint, Jokioinen and Jokioinen met the criteria of location factor low temperature (LT) [2,34]. With $15.2 \mathrm{Mg} \mathrm{ha}^{-1} \mathrm{DM}$ stalk yield and $17.8 \mathrm{Mg} \mathrm{ha}^{-1} \mathrm{DM}$ above-ground biomass yield, the Randwijk site yield was approximately twice as high as Jokioinen and Jokioinen and also higher than the average yield on favorable sites [76]. Three different dioecious varieties were grown on the Randwijk site and various monoecious and dioecious varieties on the Jokioinen and Jokioinen sites. These two locations probably yielded lower yields compared to Randwijk, as the location factors LT and UST-CL have a negative synergy [5]. Hemp thrives best on medium-heavy soils, especially on silty loam, clay loam, and sandy loam [82]. Furthermore, Bócsa et al. [75] list the following soils as suitable for hemp cultivation: loamy sand, highly loamy sand, sandy loam, loam, and heavy loam. This is somewhat in line with Von Cossel et al. [2,34], especially in the early growth phases, hemp reacts sensitively to poor soil structures [76]. Even though Von Cossel et al. [2,34] classify heavy clay soils as having low suitability for cultivation, Randwijk's yield shows that soil with heavy clay can also achieve high yields. Hemp is therefore well suited for cultivation in UST-CL locations.

\subsection{Miscanthus (Miscanthus Andersson)}

Under favorable conditions, 50\% of all Miscanthus (Miscanthus Andersson) DM yields are in the range of $13-28 \mathrm{Mg} \mathrm{ha}^{-1} \mathrm{DM}$ (Figure 2) [65]. With irrigation, yields of over $30 \mathrm{Mg} \mathrm{ha}^{-1} \mathrm{DM}$ can be achieved on sites in Southern Europe (average temperatures of $15.4^{\circ} \mathrm{C}$ ) [83]. In Central and Northern Europe (from Austria to Denmark), where global irradiation and average temperatures are lower $\left(7.3-8.0^{\circ} \mathrm{C}\right)$, yields without irrigation are typically 10-25 $\mathrm{Mg} \mathrm{ha}^{-1} \mathrm{DM}$ [83]. In a long-term test of Angelini et al. [67] without irrigation on a favored site near Pisa, the average yield over the 2nd-12th year of cultivation was $28.7 \mathrm{Mg} \mathrm{ha}^{-1} \mathrm{DM}$. As with Amaducci et al. [71], the yield of the first year of cultivation of this experiment was much lower than in the following years. From the first to second year, their yield increased; in the 3rd-8th year, the highest yields were achieved; and from the 9th-12th year, the yield decreased [67]. The complete establishment of a Miscanthus population took three to five years $[83,84]$.

For Miscanthus, 14 locations were found where field trials were conducted under UST conditions (Tables 7 and A1). Of these, seven locations meet the criteria of a UST-S, three locations meet the criteria of a UST-ST, and five locations meet the criteria of a UST-CL. 
Table 7. Annual biomass yields of Miscanthus (Miscanthus Andersson) on various unfavorable soil types (USTs) $(\mathrm{DR}=$ drought $\mathrm{S}=$ sand, $\mathrm{CL}=$ clay, $\mathrm{ST}=$ stoniness, $\mathrm{DM}=$ dry matter, $\mathrm{LRD}=$ low rooting depth $)$.

\begin{tabular}{|c|c|c|c|c|c|}
\hline Marginal Factor & $\begin{array}{c}\text { Year of } \\
\text { Cultivation }\end{array}$ & $\begin{array}{l}\text { DM Yield } \\
{\left[\mathrm{Mg} \mathrm{ha}^{-1}\right]}\end{array}$ & Place & Country & Source \\
\hline $\begin{array}{c}\text { DR; } \\
\text { UST-S }\end{array}$ & 2.-3. & 17.8 & Enna & Italy & [45] \\
\hline UST-S & 2.-3. & 24.4 & Enna & Italy & [45] \\
\hline UST-S & 1.-8. & 12.5 & $\begin{array}{c}\text { Casale } \\
\text { Monferrato }\end{array}$ & Italy & [71] \\
\hline UST-S & 4. -19 . & 9.7 & Foulum & Denmark & [85] \\
\hline UST-S & $2 .-3$. & 0.0 & & Sweden & [86] \\
\hline UST-S & 2.-3. & 32.1 & & Portugal & [86] \\
\hline UST-S; LRD & 4. & 8.9 & Durmersheim & Germany & [87] \\
\hline UST-S & 2. & 14.4 & Gutenzell & Germany & [87] \\
\hline UST-ST; & 1. & 10.8 & Near Leak Kill & USA & [88] \\
\hline UST-ST; LRD & 4. & 16 & Aberystwyth & Great Britain & [89] \\
\hline $\begin{array}{l}\text { UST-CL; } \\
\text { UST-ST }\end{array}$ & 1.-2. & 19.9 & Hohenheim "Unterer Lindenhof" & Germany & [90] \\
\hline UST-CL & 6.-8. & 7.4 & Gütersleben & Germany & [91] \\
\hline UST-CL & 3. & 25.5 & & Germany & [86] \\
\hline UST-CL & 3. & 24.3 & $\begin{array}{c}\text { Stuttgart, } \\
\text { Ihingen court }\end{array}$ & Germany & [87] \\
\hline UST-CL & 2.-3 & 0.02 & Rainton Bridge & Great Britain & [92] \\
\hline
\end{tabular}

The Hohenheim site fulfills the criteria of UST-CL and UST-ST; it has a high clay and stone content. Coarse fragments lead to high wear of tillage equipment, and clay also contributes to poorer tillage. On the other hand, the poor soil quality of clay can be positively influenced by a high stone content, since better aeration and better water infiltration is possible. In addition, the high stone content can accelerate the warming of the soil in spring, depending on the local conditions [5]. With a DM yield of $19.9 \mathrm{Mg} \mathrm{ha}^{-1}$, the Hohenheim site is in the upper half of the yield range of Miscanthus on favored sites in northern and central Europe [83]. It should be noted that this yield was determined in the first two years of cultivation. Therefore, it can be assumed that in the following years, higher or lower yields can be achieved at this location. This suggests that Miscanthus is well suited for cultivation on sites that meet the two factors UST-CL and UST-ST. The Near Leck Kill site has a soil with $31.7 \%$ rock content. The Aberystwyth site also has a high stone content of $35 \%$ and has a depth of only $50 \mathrm{~cm}$ [89]. In addition, the Aberystwyth site meets the criteria of LRD (Reinhardt, Hilgert, and Von Cossel, 2021), while the Near Leck Kill site also has SSL. Despite this, Miscanthus achieved a yield of $10.8 \mathrm{Mg} \mathrm{ha}^{-1}$ in Near Leck Kill and $16 \mathrm{Mg} \mathrm{ha}^{-1} \mathrm{DM}$ in Aberystwyth. However, this is a scientific yield from a small quadrat in a favorable year.

Two locations in Germany, examined by Clifton-Brown et al. [86] and Lewandowski et al. [87] (Table 7), achieved very similar yields of 25.5 and $24.3 \mathrm{Mg} \mathrm{ha}^{-1} \mathrm{DM}$ (both in the 3rd year of cultivation). Both locations are characterized by soils with UST-CL. These are in accordance with the upper-end yield range for Central Europe mentioned by Lewandowski et al. [83]. At $7.4 \mathrm{Mg} \mathrm{ha}^{-1} \mathrm{DM}$, the yield at Gütersleben (also UST-CL) was significantly below that of the two locations mentioned above. This was probably due to the lower annual precipitation of $603 \mathrm{~mm}$. At the German location of Clifton-Brown et al. [86] (Table 7), the annual PR was $687 \mathrm{~mm}$ and $779 \mathrm{~mm}$ at the Stuttgart site. At the Rainton Bridge site, an extremely low yield of $0.02 \mathrm{Mg} \mathrm{ha}^{-1} \mathrm{DM}$ was achieved due to the presence of not only the UST-CL factor, but also low soil drainage (LSD) conditions. This was due to poor establishment caused by the UST at this site. With developments in agronomy (e.g., a stone burier), it may well be possible to establish crops on such a site.

The yields determined on the UST-S sites vary widely, ranging from 0 to $32.1 \mathrm{Mg} \mathrm{ha}^{-1}$ DM. The Swedish site in Clifton-Brown et al. [86] did not produce any yields, as Miscanthus did not survive the first winter after planting. The reasons for this were probably (i) the low 
soil temperature which fell below the plant's required minimum, and (ii) that the in vitro plants may not grow sufficient rhizomes for the plant to overwinter well. On the site in Portugal, which also meets the factor UST-S, high average yields of $32.1 \mathrm{Mg} \mathrm{ha}^{-1} \mathrm{DM}$ were achieved in the second and third years of cultivation. This site was irrigated. In the 3rd year of cultivation, the yield was $36.4 \mathrm{Mg} \mathrm{ha}^{-1} \mathrm{DM}$, which is comparable to the data of Lewandowski et al. [83] for a site in Southern Europe with irrigation, and higher compared to an unirrigated site in Southern Europe [67]. Compared to the location in Portugal, the yield in Denmark was much lower, with $9.7 \mathrm{Mg} \mathrm{ha}^{-1} \mathrm{DM}$. With $657 \mathrm{~mm}$ annual rainfall and no irrigation, the water supply of Miscanthus in Denmark was lower compared to Portugal, and in addition, the annual average temperature was only $8{ }^{\circ} \mathrm{C}$ in Denmark, compared to $15.4^{\circ} \mathrm{C}$ in Portugal. Furthermore, the sand content in Portugal was lower with $76.2 \%$ compared to Denmark with $84.4 \%$. The Casale Monferrato site (in Italy) achieved a lower yield than Portugal with $12.5 \mathrm{Mg} \mathrm{ha}^{-1} \mathrm{DM}$ due to rainfed conditions. This could also be due to a high sand content of $90 \%$ in Casale Monferrato. Another site with sandy soil is Gutenzell. On this site, Miscanthus achieved a yield of $14.4 \mathrm{Mg} \mathrm{ha}^{-1} \mathrm{DM}$, which is lower than in Portugal, but within the yield range of sites in Central Europe [83]. The Enna site, along with Portugal, achieved the highest yield of all UST-S sites found, with $24.4 \mathrm{Mg} \mathrm{ha}^{-1}$ DM, under an irrigation of $75 \%$ ET (Table A1).

Following Von Cossel et al. [2,34], Miscanthus showed low suitability for cultivation on sandy soils (depending on precipitation and irrigation conditions), good suitability for cultivation on clay soils, and medium suitability for cultivation on heavy clay soils. Ramirez-Almeyda et al. [8] indicate that Miscanthus is moderately suitable for cultivation on sandy and clay soils (provided they make it through the first few months after planting) and poorly suitable for cultivation on heavy clay soils. The most important requirement that Miscanthus places on the soil is its water holding capacity [93]. Although it is easier to establish on light soils, it produces higher yields on heavy soils over several years [83]. Even though Panacea [94] indicates that Miscanthus can only grow poorly on stony soils, the published plot trials show this is not always the case. These sites each meet the criteria for another marginal factor and still achieved mediocre yields. This suggests that Miscanthus is well suited for cultivation on sites with only UST-ST. In addition, the sites found indicate that this plant is very suitable for cultivation on UST-CL sites in Central Europe with a good water supply. For UST-S sites in Southern Europe, Miscanthus shows good suitability for cultivation, provided sufficient irrigation is provided. A very high sand content $(>75 \%)$ in the soil results in lower and more variable annual yields than a site with a reduced sand fraction.

\subsection{Poplar (Populus L.)}

The yield results from the systematic literature search with the corresponding indication of the respective agricultural marginality constraints are listed in Table 8. In order to better assess the suitability of poplar cultivation on marginal agricultural lands, the yield figures determined are compared with those on favored sites. In a systematic literature search and meta-analysis of Laurent et al. [65] on poplar yields, it was found that $50 \%$ of all yield data are in the range of 7-10 $\mathrm{Mg} \mathrm{ha}^{-1} \mathrm{DM}$ (Figure 2). Berendonk et al. [61] indicate that a yield of 8-12 Mg ha ${ }^{-1} \mathrm{DM}$ can be expected for short rotation plantations. On a favorable location in Mira in Northern Italy, a yield of $20 \mathrm{Mg} \mathrm{ha}^{-1} \mathrm{DM}$ in the second rotation and $15 \mathrm{Mg} \mathrm{ha}^{-1} \mathrm{DM}$ in the first rotation was achieved [95]. Seven sites with UST were found for poplar, five of which are UST-S and two of which are UST-CL (Tables 8 and A1). 
Table 8. Annual biomass yields of poplar (Populus L.) under unfavorable soil type (USTs) conditions $(\mathrm{DR}=$ drought, $\mathrm{S}=$ sand, $\mathrm{CL}=$ clay, $\mathrm{LSD}=$ low soil drainage, $\mathrm{DM}=$ dry matter).

\begin{tabular}{|c|c|c|c|c|c|}
\hline $\begin{array}{l}\text { Marginal } \\
\text { Factor }\end{array}$ & $\begin{array}{l}\text { Age of Tree } \\
\text { (Trunk) }\end{array}$ & $\begin{array}{l}\text { DM Yield } \\
{\left[\mathrm{Mg} \mathrm{ha}^{-1}\right]}\end{array}$ & Place & Country & Source \\
\hline $\begin{array}{c}\text { DR; } \\
\text { UST-CL }\end{array}$ & 2 & 1.8 & Rutigliano & Italy & [96] \\
\hline UST-CL & 2 & 6.1 & Bigarello & Italy & [95] \\
\hline UST-S & 2 & 7.2 & $\begin{array}{c}\text { Casale } \\
\text { Monferrato }\end{array}$ & Italy & [71] \\
\hline UST-S & 3 & 7.3 & Soria & Spain & [97] \\
\hline UST-S & 2 & 7.7 & Potsdam-Bornim & Germany & [80] \\
\hline UST-S & 4 & 5.5 & Olsztyn & Poland & {$[98,99]$} \\
\hline LSD; UST-S & 2 & 8.1 & Lochristi & Belgium & {$[100,101]$} \\
\hline
\end{tabular}

The Lochchristi site also shows low soil drainage (LSD), while the Rutigliano site meets the criteria for DR. The Casale Monferrato site has a very high sand content of over $90 \%$. Here, poplar achieved a yield of $7.2 \mathrm{Mg} \mathrm{ha}^{-1} \mathrm{DM}$. At the Soria site, a very similar yield of $7.3 \mathrm{Mg} \mathrm{ha}^{-1} \mathrm{DM}$ was obtained over three rotations $\left(9 \mathrm{Mg} \mathrm{ha}^{-1} \mathrm{DM}\right.$ in the first and second rotation and $4 \mathrm{Mg} \mathrm{ha}^{-1} \mathrm{DM}$ in the third) [97]. At the Potsdam-Bornim site, a yield of $7.7 \mathrm{Mg} \mathrm{ha}^{-1} \mathrm{DM}$ was achieved. The yield of the genotype Japan 105 was over $9 \mathrm{Mg} \mathrm{ha}^{-1}$ DM [80]. The Olsztyn site achieved the lowest yield of $5.5 \mathrm{Mg} \mathrm{ha}^{-1} \mathrm{DM}$ of all UST-S sites investigated with poplar. It also has a very high sand content of $90 \%$ of the soil. On this site, however, a yield of $10.6 \mathrm{Mg} \mathrm{ha}^{-1} \mathrm{DM}$ could be achieved with lignin and mineral fertilization [98,99]. The Lochchristi site achieved the highest yield of all UST-S sites at 8.1 $\mathrm{Mg} \mathrm{ha}^{-1} \mathrm{DM}$. The yields of four of the five sites found are slightly below the yield in Berendonk et al. [61]. An exception is Lochchristi; the yield achieved on this corresponds to the yield on favored sites [61].

Eight different genotypes were grown on the Bigarello site. These yielded an average of $6.1 \mathrm{Mg} \mathrm{ha}{ }^{-1} \mathrm{DM}$ over two rotations, which was slightly below the yield of Berendonk et al. [61] for poplar. The highest yield in the second rotation was achieved by the genotype $83,148,041$ (P. $x$ canadensis) with $11.1 \mathrm{Mg} \mathrm{ha}^{-1}$. The Rutigliano site achieved a yield of $1.8 \mathrm{Mg} \mathrm{ha}^{-1} \mathrm{DM}$, which is much lower than the yield stated in Berendonk et al. [61]. Optimum conditions for poplar are soils with a maximum clay content of 30\% [95].

According to Von Cossel et al. [2,34], poplar has a low suitability for cultivation in sandy soils, very good to medium suitability for clay soils and, low suitability for heavy clay soils. Ramirez-Almeyda et al. [8] also classify the suitability for cultivation in this way. Only heavy clay soils are classified as unsuitable for poplar cultivation. For soils with UST-CL, this information can be confirmed with the yields of the identified sites. They show a medium suitability for cultivation. The yields of the locations found for UST-S do not match the classifications of Ramirez-Almeyda et al. [8] and Von Cossel et al. [34]. It can be assumed that poplar also has medium suitability for cultivation in soils with UST-S, provided it has a high water table or high precipitation.

\subsection{Reed Canary Grass (Phalaris arundinacea L.)}

Reed canary grass achieves biomass yields of $5-13 \mathrm{Mg} \mathrm{ha}^{-1} \mathrm{DM}$ under favorable conditions $[93,102,103]$. For example, reed canary grass achieved an average yield of $8 \mathrm{Mg} \mathrm{ha}^{-1} \mathrm{DM}$ (yields of 3.9-13.8 $\mathrm{Mg} \mathrm{ha}^{-1} \mathrm{DM}$ were measured) on four different favored sites in the Czech Republic from the 2nd-6th year of cultivation [104]. Eight locations were found that meet the criteria for UST (Tables 9 and A1). 
Table 9. Annual biomass yields of reed canary grass (Phalaris arundinacea L.) under unfavorable soil types (USTs) conditions ( $\mathrm{S}=$ sand, $\mathrm{CL}=$ clay, $\mathrm{ST}=$ stoniness, $\mathrm{DM}=$ dry matter, $\mathrm{LRD}=$ low rooting depth).

\begin{tabular}{|c|c|c|c|c|c|}
\hline Marginal Factor & $\begin{array}{c}\text { Year of } \\
\text { Cultivation }\end{array}$ & $\begin{array}{l}\text { DM Yield } \\
{\left[\mathrm{Mg} \mathrm{ha}^{-1}\right]}\end{array}$ & Place & Country & Source \\
\hline UST-S & 3.-7. & 3 & Willsboro (1S) & USA & [105] \\
\hline UST-CL & 3.-7. & 5 & Willsboro (SCL) & USA & [105] \\
\hline UST-S & 2.- -4 . & 14.3 & Jyndevad & Denmark & [6] \\
\hline UST-S & 2.-4. & 16 & Foulum & Denmark & [6] \\
\hline $\begin{array}{l}\text { UST-CL } \\
\text { UST-S; }\end{array}$ & 2.-3. & 14 & Carlow (Farrell's Field) & Ireland & [106] \\
\hline $\begin{array}{l}\text { UST-ST; } \\
\text { LRD }\end{array}$ & 2.-3. & 13 & Carlow (Far Avenue Meadow) & Ireland & [106] \\
\hline UST-CL & 2.-3. & 5.5 & Rainton Bridge & Great Britain & [92] \\
\hline UST-CL & 1.-2. & 5.6 & Burlington & USA & [107] \\
\hline
\end{tabular}

Of these, three are UST-S, four are UST-CL, and one is UST-ST. The Carlow site (Far Avenue Meadow) also meets the criteria for the LRD factor. The Willsboro (SCL), Rainton Bridge, and Burlington sites also have low soil drainage. Willsboro (IS) also has the factor UST-S. Furthermore, Willsboro (IS) and Willsboro (SCL) fulfill the criteria of factor LT. The soil at the Jyndevad site has a sand content of $88 \%$ and a yield of $14.3 \mathrm{Mg} \mathrm{ha}^{-1}$. The Foulum site has a slightly lower sand content of $78 \%$ and achieved a higher yield of $16 \mathrm{Mg} \mathrm{ha}^{-1}$. Both yields are higher than the yield on favored sites [93]. At the Willsboro (IS) site, a low yield of $3 \mathrm{Mg} \mathrm{ha}^{-1} \mathrm{DM}$ was achieved. With NPK fertilization, however, the yield could be increased to $9 \mathrm{Mg} \mathrm{ha}^{-1}$. The Carlow site (Far Avenue Meadow) achieved a yield of $13 \mathrm{Mg} \mathrm{ha}^{-1} \mathrm{DM}$, which corresponds to the yield on favored sites [93].

The soil at the Carlow site (Farrels field) has a clay content of over $45 \%$ and yielded $14 \mathrm{Mg} \mathrm{ha}^{-1} \mathrm{DM}$ [106]. This yield is higher than the yield on favored sites [17]. On Willsboro (SCL), a yield of $5 \mathrm{Mg} \mathrm{ha}^{-1} \mathrm{DM}$ could be achieved without fertilization and $11 \mathrm{Mg} \mathrm{ha}^{-1}$ with $\mathrm{N}$-fertilization [105]. Furthermore, in Burlington, a higher fertilization level with $253 \mathrm{~kg} \mathrm{~N} \mathrm{ha}^{-1}$ resulted in a higher crop yield of $10.5 \mathrm{Mg} \mathrm{ha}^{-1} \mathrm{DM}$ [107].

The assessments of the suitability for the cultivation of reed canary grass in RamirezAlmeyda et al. [8] and in Von Cossel et al. [2,34] agree. They state that this crop's suitability for cultivation on sand is low, on loam very good, on clay moderate, and on heavy clay low. The results of this work partly contradict these statements. They rather indicate good suitability for cultivation on soils with high sand content and also on soils with high clay content. That the soil type influences the yield and that soil with less than $15 \%$ clay has higher yields than clay soil [108] could not be confirmed with the yield results of the locations found. A greenhouse trial in Freiberg showed that reed canary grass could also grow in pots with $100 \%$ sand and be fertilized with an NPK solution $[109,110]$. Reed canary grass can grow in a variety of soils [104] and shows good suitability for cultivation on sites with UST-S, UST-CL, and UST-ST, as long as enough water and nutrients are available.

\subsection{Sorghum (Sorghum bicolor L. Moench)}

Under favorable conditions, Sorghum reaches above-ground DM yields of $15-20 \mathrm{Mg}$ $\mathrm{DM} \mathrm{ha}^{-1}$ [111]. For example, on a favored site in Cadriano, Italy, fiber and sweet Sorghum yielded an average of $20.8 \mathrm{Mg} \mathrm{DM} \mathrm{ha}^{-1}$ [112]. Three sites were found, which meet the criteria of a UST-S and one site, which meets the criteria of a UST-CL (Tables 10 and A1). 
Table 10. Annual stalk and biomass yields of Sorghum (Sorghum bicolor L. Moench) on marginal sites characterized by unfavorable soil types (USTs) (LT = low temperature; DR = drought, $\mathrm{S}=$ sand, $\mathrm{DM}=$ dry matter, $\mathrm{tE}=$ theoretical ethanol).

\begin{tabular}{ccccccc}
\hline $\begin{array}{c}\text { Marginality } \\
\text { Constraints }\end{array}$ & $\begin{array}{c}\text { DM Yield } \\
{\left[\mathbf{M g ~ h a}^{-1}\right]}\end{array}$ & $\begin{array}{c}\text { Stem DM } \\
\text { Yield } \\
{\left[\mathbf{M g ~ h a}^{-1}\right]}\end{array}$ & $\begin{array}{c}\text { tE Yield } \\
{\left[\mathbf{L ~ h a}^{-\mathbf{1}}\right]}\end{array}$ & Place & Country & Source \\
\hline $\begin{array}{c}\text { LT; DR; UST-S } \\
\text { DR; }\end{array}$ & 6.7 & 4.5 & 2135 & Wushen & China & {$[113]$} \\
UST-S & 13.9 & 11.8 & 2491 & Ganquika & China & {$[114]$} \\
DR; & 17.0 & & 2150 & Big Spring & USA & {$[115]$} \\
UST-S & 23.0 & & 3000 & Big Spring & USA & {$[115]$} \\
UST-S & 16.2 & & 4212 & El Centro & USA & {$[116]$} \\
UST-S & & & & & & \\
\hline
\end{tabular}

Ganquika, like the Wushen site, also meets the criteria of a DR site. The Big Spring site achieved a yield of $23 \mathrm{Mg} \mathrm{ha}^{-1} \mathrm{DM}$ in the trial version with irrigation. This yield is comparable to the yield on favored sites [111] and is slightly higher than the yield achieved in Cadriano, Italy (favored location) [112]. The theoretical ethanol yield at Big Spring was $3000 \mathrm{~L} \mathrm{ha}^{-1}$. This is comparable to a favorable location on a silty clayey loamy soil with $3209 \mathrm{~L} \mathrm{ha}^{-1}$ [117]. Compared to the favored site in Weslaco, USA, with a clayey loamy soil, on which a theoretical ethanol yield of $2601 \mathrm{~L} \mathrm{ha}^{-1}$ was achieved [118], the amount of ethanol produced at Big Spring is higher. The biomass yield at Ganquika was lower compared to Big Spring and also compared to favored sites [111]. The theoretical ethanol yield (2491 L ha-1) was also lower in Ganquika compared to Big Spring. Presumably, the yield on Ganquika is lower because the location factors DR and UST-S show a negative synergy [5]. For this reason, and because the Wushen site also has the factor LT, the yield at this site is much lower than at the favored sites [111]. The ethanol content of Wushen, at $2135 \mathrm{~L} \mathrm{ha}^{-1}$, is also below that of Big Spring. At the El Centro site, Sorghum was grown in one year over three growing seasons, with a yield of $16.2 \mathrm{Mg} \mathrm{ha}^{-1} \mathrm{DM}$ in the second growing season [116]. This yield is more or less equal to that obtained in favored locations [111,112].

As shown, Sorghum can grow in a wide variety of soils, including clay and sandy soils [119]. Clay soils are ideal for the cultivation of Sorghum [119-121]. According to the division elaborated by Von Cossel et al. [2,34], Sorghum is unsuitable for cultivation on sandy soils and is very suitable for cultivation on clay and heavy clay soils. The yield results at the sites with UST-S contradict this classification, whereas it is confirmed by the results at the sites with UST-CL. Sorghum has good suitability for cultivation on sites with UST-S and very good suitability for cultivation on sites with UST-CL.

\subsection{Switchgrass (Panicum virgatum L.)}

For switchgrass grown under favorable conditions, $50 \%$ of all DM yields are in the range of 7-12 $\mathrm{Mg} \mathrm{ha}^{-1}$ (Figure 2) [65]. In Europe, switchgrass DM yields range from 5-23 Mg ha ${ }^{-1}$ [93]. According to Parrish et al. [122], switchgrass produces DM yields of about $15 \mathrm{Mg} \mathrm{ha}^{-1}$ on favored sites over a longer period of time. Panacea [123] reported switchgrass DM yields of $10-25 \mathrm{Mg} \mathrm{ha}^{-1}$ on favorable sites. Nine locations were found for the agricultural marginality constraint UST (Tables 11 and A1). 
Table 11. Annual biomass yields of switchgrass (Panicum virgatum L.) on different types of marginal agricultural land characterized inter alia by unfavorable soil types (USTs) $(\mathrm{DR}=$ drought, $\mathrm{S}=$ sand, $\mathrm{CL}=$ clay, $\mathrm{ST}=$ stoniness, $\mathrm{DM}=\mathrm{dry}$ matter).

\begin{tabular}{|c|c|c|c|c|c|c|}
\hline $\begin{array}{c}\text { Marginal } \\
\text { Factor }\end{array}$ & $\begin{array}{c}\text { Year of } \\
\text { Cultivation }\end{array}$ & $\begin{array}{l}\text { DM Yield } \\
{\left[\mathrm{Mg} \mathrm{ha}^{-1}\right]}\end{array}$ & Ecotype & Place & Country & Source \\
\hline UST-CL & 3.-5. & 0 & Upland & Rainton Bridge & Great Britain & [92] \\
\hline UST-CL & 3.-7. & 12.5 & Upland & Willsboro (SCL) & USA & [105] \\
\hline UST-S & 3.-7. & 10 & Upland & Willsboro (1S) & USA & [105] \\
\hline $\begin{array}{c}\text { UST-S; } \\
\text { DR }\end{array}$ & 5., 6., 8., 9 . & 9.8 & Upland & Ganqika & China & {$[114,124]$} \\
\hline UST-S & 1.-3. & 4.5 & Upland & Becker & USA & [125] \\
\hline UST-S & 1.-3. & 3.5 & Lowland & Becker & USA & [125] \\
\hline UST-S & $1 .-8$. & 7.5 & Lowland & Casale Monferrato & Italy & [71] \\
\hline UST-ST & 2. & 15 & Lowland & Mason & USA & [126] \\
\hline UST-ST & 1. & 11 & & Near Leak Kill & USA & [88] \\
\hline
\end{tabular}

Of these, two fulfill the marginality thresholds of UST-CL, five of UST-S, and two of UST-ST. The Near Leak Kill site has a stone content of 31.7\% in the soil and additionally an SSL. Switchgrass achieved a yield of $11 \mathrm{Mg} \mathrm{ha}^{-1} \mathrm{DM}$ in the first year of cultivation. This corresponds to the yields on favored sites [123]. Switchgrass grown on sites with only UST-ST could achieve even higher yields in further growing years than in the first growing year on the Near Leck Kill site. On the Mason site, the lowland variety Nebraska 29 yielded $15 \mathrm{Mg} \mathrm{ha}^{-1} \mathrm{DM}$. This corresponds to the yield on favored sites [122]. The described results confirm the statement of Parenti et al. [74] that switchgrass has a good cultivation suitability for sites with UST-ST.

On the Willsboro (SCL) with UST-CL and Willsboro (IS) with UST-S sites, the Cavein-Rock (Upland) variety was cultivated. The yield on Willsoboro (IS) was $10 \mathrm{Mg} \mathrm{ha}^{-1}$ $\mathrm{DM}$, which is slightly below the yield of $12.5 \mathrm{Mg} \mathrm{ha}^{-1} \mathrm{DM}$ on Willsboro (SCL). Higher yields were produced on both sites with NPK fertilization: Willsboro (IS) $12.5 \mathrm{Mg} \mathrm{ha}^{-1} \mathrm{DM}$ and Willsoboro (SCL) $14.5 \mathrm{Mg} \mathrm{ha}^{-1}$ DM [105]. The Ganquika site has UST-S and DR. At this site, the Blackwell upland variety achieved a yield of $9.8 \mathrm{Mg} \mathrm{ha}^{-1} \mathrm{DM}$. This is slightly lower than the yields on favored sites [123]. At the Becker site, the Shawnee and Sunburst upland varieties and the Liberty lowland variety were cultivated. In the first three years of cultivation, Liberty achieved a mediocre yield of $3.5 \mathrm{Mg} \mathrm{ha}^{-1} \mathrm{DM}$ without fertilization, while Shawnee and Sunburst yielded $4.5 \mathrm{Mg} \mathrm{ha}^{-1} \mathrm{DM}$. With a fertilization of $112 \mathrm{~kg} \mathrm{ha}^{-1}$ $\mathrm{N}$, the yield of Liberty at $7 \mathrm{Mg} \mathrm{ha}^{-1}$ and of Sunburst and Shawnee at $11 \mathrm{Mg} \mathrm{ha}^{-1} \mathrm{DM}$ was significantly higher than without fertilization. The marginal agricultural land Becker also has low soil moisture. Lowland varieties like Liberty are sensitive to water stress, whereas upland varieties are better adapted to dry conditions [125]. The soil of the Casale Monferrato site has a $90 \%$ sand content. The Lowland variety Alamo produced a yield of $7.5 \mathrm{Mg} \mathrm{ha}^{-1} \mathrm{DM}$ on this site. This yield is slightly lower than the yield on the other site [123].

According to Parenti et al. [74], switchgrass is very suitable for sandy soils and only slightly suitable for clay soils. Von Cossel et al. [34] and Ramirez-Almeyda et al. [8] indicate that switchgrass has medium cultivation suitability for sandy soils, very good suitability for clay soils, and medium suitability for clay soils. Switchgrass is declared unsuitable for cultivation on heavy clay soils Ramirez-Almeyda et al. [8]. In general, the ecotype Upland is suitable for sandy soils, and the Lowland ecotype is only moderately suitable for clay soils. Upland varieties are moderately suitable for cultivation on clay soils.

\subsection{Willow (Salix L.)}

For willow, $50 \%$ of all DM yield data are in the range of 8-13 $\mathrm{Mg} \mathrm{ha}^{-1}$ [65]. According to [61], a DM yield of $8-12 \mathrm{Mg} \mathrm{ha}^{-1}$ is expected for short rotation plantations. Under optimal conditions, willow can achieve DM yields of $20-30 \mathrm{Mg} \mathrm{ha}^{-1} \mathrm{DM}$ [42]. On a favored 
site in Poland, willow produced an average yield of $13.7 \mathrm{Mg} \mathrm{ha}^{-1} \mathrm{DM}$ and a maximum yield of $16 \mathrm{Mg} \mathrm{ha}^{-1} \mathrm{DM}$ [127].

For willow grown under UST conditions, 19 locations were found (Tables 12 and A1).

Table 12. Annual biomass yields of willow (Salix L.) on marginal sites prone to unfavorable soil types (USTs) (S = sand, $\mathrm{CL}=$ clay, $\mathrm{ST}=$ stoniness, $\mathrm{DM}=$ dry matter $)$.

\begin{tabular}{|c|c|c|c|c|c|}
\hline $\begin{array}{l}\text { Marginality } \\
\text { Factor }\end{array}$ & $\begin{array}{l}\text { Age of Tree } \\
\text { (Trunk) }\end{array}$ & $\begin{array}{l}\text { DM Yield } \\
{\left[\mathrm{Mg} \mathrm{ha}^{-1}\right]}\end{array}$ & Place & Country & Source \\
\hline UST-S & 3 & 6.7 & St. Lawrence (sL) & Canada & {$[128]$} \\
\hline UST-CL & 3 & 3.1 & Saskatoon & Canada & {$[129,130]$} \\
\hline UST-CL & 3 & 12.8 & St. Lawrence (SCL) & Canada & [128] \\
\hline UST-CL & 3 & 13.0 & Alma & Canada & [131] \\
\hline UST-CL & 2 & 2.5 & La Morandiere & Canada & [131] \\
\hline UST-CL & 3 & 11.5 & Beloeil & Canada & [131] \\
\hline UST-CL & 3 & 11.5 & La Pocatiere & Canada & [131] \\
\hline UST-S & 2 & 4.8 & Casale Monferrato & Italy & [71] \\
\hline UST-S & 2 & 6.0 & Potsdam-Bornim & Germany & [80] \\
\hline UST-S & 4 & 5.1 & Olsztyn & Poland & {$[98,99]$} \\
\hline UST-S & 3 & 2.9 & Lezany & Poland & [127] \\
\hline UST-S & 3 & 4.0 & Hojmark & Denmark & [132] \\
\hline UST-S & 2 & 4.0 & Odum & Denmark & [132] \\
\hline UST-S & 3 & 8.2 & Foulum & Denmark & [132] \\
\hline UST-S & 3 & 5.3 & Jyndevad & Denmark & [132] \\
\hline UST-S & 2 & 2.0 & Saint-Roch-de-l Achigan, Sandy field & Canada & [133] \\
\hline UST-ST & 2 & 1.0 & Saint-Roch-de-l Achigan, Rocky field & Canada & [133] \\
\hline UST-CL & 2 & 0.0 & Rainton Bridge & Great Britain & [92] \\
\hline UST-S & 3 & 4.2 & Foersom & Denmark & [132] \\
\hline
\end{tabular}

Of these, eleven have a UST-S, seven a UST-CL, and one a UST-ST. The yields on sites with UST-S are in the range of 2 to $8.2 \mathrm{Mg} \mathrm{DM} \mathrm{ha}^{-1}$. With the exception of the Foulum site with a yield of $8.2 \mathrm{Mg} \mathrm{ha}^{-1} \mathrm{DM}$, all yields of the sites with UST-S are lower than those on favorable sites [61]. At the Saint Roch (Sandy) site, the unfertilized trial variant achieved $2 \mathrm{Mg} \mathrm{DM} \mathrm{ha}{ }^{-1}$, while the other variant with a fertilization of $75 \mathrm{~kg} \mathrm{~N} \mathrm{ha}^{-1}$ produced a significantly higher yield of $3 \mathrm{Mg} \mathrm{DM} \mathrm{ha}{ }^{-1}$ [133]. This site has the third-highest sand content of all sites found, at $89 \%$. The Foersom site has the highest sand content (95\%) and achieved a DM yield of $4.2 \mathrm{Mg} \mathrm{ha}^{-1}$. The results of all sites with UST-S show that a high sand content leads to yield losses in comparison to favored sites. It can therefore be assumed that willow is suitable for medium cultivation at sites with UST-S.

The yields on sites with UST-CL range from 0 to $13 \mathrm{Mg} \mathrm{DM} \mathrm{ha}^{-1}$. The Rainton Bridge site has LSD in addition to UST-CL. The Tora (SW910007) and Torhild (SW930725) genotypes of Salix schwerinii $x$ Salix viminalis cultivated on it grew very poorly. For this reason, a very low DM yield of $0.04 \mathrm{Mg} \mathrm{ha}^{-1}$ was achieved [92]. The Beloeil and La Pocatiere sites both have a UST-CL only and achieved a DM yield of $11.5 \mathrm{Mg} \mathrm{ha}^{-1}$ each, which is comparable to the yield in Berendonk et al. [61] and corresponds to the yield mentioned above. At the Alma site, willow achieved a yield of $13 \mathrm{Mg} \mathrm{DM} \mathrm{ha}^{-1}$ despite UST-CL and additional LSD. These results show that willow is well suited for cultivation on sites with UST-CL.

The soil of the Saint Roch (Rocky) site contains $30 \%$ stones (1-5 cm in size). Salix miyabeana Seeman SX64 and SX61 were grown on it, and a DM yield of $1 \mathrm{Mg} \mathrm{ha}^{-1}$ (without fertilization) was achieved. With a fertilization of $75 \mathrm{~kg} \mathrm{~N} \mathrm{ha}^{-1}$, a significantly higher yield of $1.5 \mathrm{Mg} \mathrm{DM} \mathrm{ha}{ }^{-1}$ was achieved on this site [133]. Both yield values are far below those on favored sites [61]. On Saint Roch (Rocky), willow produced little biomass because the soil was too difficult for the roots of this plant to penetrate due to its high stone content [133]. Sites with a UST-ST are only slightly suitable for the cultivation of willow.

According to the division into the categories established by Von Cossel et al. [2,34], willow is suitable for growing on sandy soils, very well suited on clay soils, moderately 
suited on clay soils, and poorly suited on heavy clay soils. The categorization reported by Ramirez-Almeyda et al. [8] is in accordance with Von Cossel et al. [2,34], except for heavy clay soil, which is considered unsuitable for willow cultivation.

\section{Suitability Ranking of Industrial Crops for Cultivation on USTs}

Based on the results from the literature review, some contrasting objective cultivation suitability values were derived for the selected industrial crops on unfavorable soil types sandy, clayey, and stony soil (Table 13).

Table 13. Classification of cultivation suitability per crop and soil type: 4 = very good suitability for cultivation (dark green), 3 = good suitability for cultivation (light green), 2 = moderate suitability for cultivation (orange), $1=$ poor suitability for cultivation (red). Suitability values in brackets were derived from other literature because no references were found that provide the exact combination of the crop and soil type (UST = unfavorable soil type, $\mathrm{S}=$ sand, $\mathrm{CL}=\mathrm{clay}, \mathrm{ST}=$ stones, Lo = lowland, $\mathrm{Up}=$ upland). Where no alternative literature was found either, the field was left blank as no conclusions about suitability could be made.

\begin{tabular}{|c|c|c|c|c|}
\hline \multirow{2}{*}{ Crop } & & \multicolumn{3}{|c|}{ UST } \\
\hline & & $\mathbf{S}$ & CL & ST \\
\hline \multicolumn{2}{|l|}{ Camelina (Camelina sativa L. Crantz) } & 3 & $2-3$ & \\
\hline \multicolumn{2}{|l|}{ Cardoon (Cynara cardunculus L.) } & 3 & 3 & \\
\hline \multicolumn{2}{|c|}{ Crambe (Crambe abyssinica Hochst. Ex R.E.Fr.) } & (3) & 2 & (1) \\
\hline \multicolumn{2}{|c|}{ Cup plant (Silphium perfoliatum L.) } & 3 & & \\
\hline \multicolumn{2}{|l|}{ Giant reed (Arundo donax L.) } & 3 & 2 & (3) \\
\hline \multicolumn{2}{|l|}{ Hemp (Cannabis sativa L.) } & 2 & 3 & 3 \\
\hline \multicolumn{2}{|l|}{ Miscanthus (Miscanthus Andersson) } & 3 & 4 & 3 \\
\hline \multicolumn{2}{|c|}{ Poplar (Populus L.) } & 2 & 2 & \\
\hline \multicolumn{2}{|c|}{ Reed canary grass (Phalaris arundinacea L.) } & 3 & 3 & 3 \\
\hline \multicolumn{2}{|c|}{ Sorghum (Sorghum bicolor L. Moench) } & 3 & 3 & \\
\hline \multirow{3}{*}{ Switchgrass (Panicum virgatum L.) } & Lo & 2 & (2) & 3 \\
\hline & Up & 3 & 2 & 3 \\
\hline & & 2 & 3 & 1 \\
\hline
\end{tabular}

Industrial crops whose suitability for cultivation on sites with a certain marginality is rated as good or very good may be recommended for cultivation. Good and very good suitability for cultivation means that yields comparable to favorable locations can be achieved on marginal sites. The expected yields are listed below.

The following plants are well suited for cultivation on sites with a marginality due to UST-S: Camelina, cardoon, giant reed, Miscanthus, upland switchgrass, reed canary grass, cup plant, and Sorghum showed well suitability for sites characterized by sandy soil (UST-S) (Table 13). The highest yields can be expected with the cultivation of giant reed, cardoon, and Sorghum under UST-S conditions. Other cultivation parameters, such as the temperature and the sunshine duration, are also important. Considering these, the best recommendation would be to grow cardoon and giant reed in southern Europe, Sorghum in southern and central Europe, reed canary grass in central and northern Europe, whereas Miscanthus, camelina, and switchgrass could grow on UST-S sites throughout Europe [134]. UST-S conditions, however, can place great demands on agricultural practices, depending on the location, as already mentioned to some extent in the previous sections. For example, great importance must be placed on site-specific fertilization and water supply, as sandy soils tend to be low in nutrients and have low field capacity. Depending on other site conditions, such as steep slopes or close proximity to groundwater protection areas, the requirement of fertilization or irrigation may preclude the cultivation of the industrial crops mentioned above, even if they are suitable in principle.

On marginal agricultural land characterized by UST-CL (clayey soil), the following industrial crops show good suitability for cultivation: hemp, cardoon, Sorghum, reed canary grass, and willow (Table 13). For the industrial crop Miscanthus, a very good suitability for cultivation was revealed. But again, other growth conditions than the soil type are, of 
course, important as well. Thus, high yields of Miscanthus on sites with UST-CL can only be expected under warm climatic conditions with a long growing season and sufficient water supply. Hemp is suitable for cultivation throughout Europe, but care must be taken to select only varieties approved in the EU [135] in order to meet not only the growing conditions but also the respective legal requirements. Cardoon is suitable for cultivation in southern Europe, Sorghum in southern and central Europe, reed canary grass and willow in central and northern Europe, and Miscanthus throughout Europe [134].

For UST-ST, based on the results of the literature review, the selection of suitable industrial crops is much lower compared to UST-S and UST-CL (Table 13). Only the industrial crops hemp, Miscanthus, switchgrass, and reed canary grass are considered suitable, with the lowest DM yield level expected for hemp (Figure 2).

\section{Outlook}

The sparse data on UST-ST (Table 13, Figure 2) is a good example of how much information is still lacking on the adaptive capabilities and resulting performance spectra of the known industrial crops on marginal agricultural land. In order to avoid data patchworks, such as those uncovered in this review, in the future, research institutions should be better networked and coordinated with each other. This applies to research networks that serve food security, for example, the European Consortium for Open Field Experimentation (ECOFE), and those that serve biomass security. Biomass security here refers to the long-term availability of biomass types other than those used for food and feed supply. Even though biomass security does not have the same priority as food security, a sustainable transition to a bioeconomy may only be possible if long-term planning research networks that deal with industrial crops are created. A carefully thought-out and wellcoordinated network of field trial stations such as ECOFE [136] may be necessary to provide a clearer picture of where which industrial crops are performing well, especially considering the currently accelerating dynamics of climate change $[137,138]$ and the growing conflicts of interest over the use of available land [139]. Therefore, it should be thoroughly investigated whether such networks should become part of a permanent state-funded infrastructure in order to run as successfully as possible. It is true that there are already a large number of long-term field trials with industrial crops in the EU $[140,141]$, some of which could be passed on from one project to the next. However, this is not the rule, with the consequence that many field trials cannot be monitored continuously over several years or, in the worst case, have to be abandoned despite their great potential for use as long-term studies. In addition, the number of participating institutions that can conduct representative field trials is severely limited in such short-term projects (duration of up to five years). This is because, in addition to crop-related tasks, there are always a variety of other areas of work that must be included in the proposal (e.g., sustainability assessment, value chain development, dissemination, etc.) without which an acceptance of the proposals is not realistic. As already mentioned, it is important to cover as broadly as possible the marginality constraints to identify relevant combined effects and to develop possible agronomic solutions, including, for example, the site-specific selection of the most suitable crop or crop rotation. An important first approach could be to establish a good database of all trial sites (at EU and global level) with accurate information on the crops and genotypes used, the soil and climatic characteristics of the sites, the exact yields per year, and the exact management measures. This will allow better comparisons and informed decisions on where to grow which crops, or where there are synergies in field trials and possible networks that could be formed to start joint long-term planning.

The present study should thus be considered as only one part of the necessary basis to enable sustainable biomass production from industrial cropping systems on marginal agricultural land characterized by UST conditions in the future. The development of site-specific industrial cropping systems must always take into account the overall site conditions, including environmental conditions (especially other marginality constraints) and socio-economic requirements. 
Author Contributions: Conceptualization: J.R. and M.V.C.; methodology: J.R. and M.V.C.; validation, J.R., P.H. and M.V.C.; investigation: J.R.; writing—original draft: J.R., P.H. and M.V.C.; writingreview and editing: M.V.C.; resources: J.R.; visualization: J.R. and M.V.C.; funding acquisition, M.V.C.; supervision: M.V.C. All authors have read and agreed to the published version of the manuscript.

Funding: This research received funding from the European Union's Horizon 2020 research and innovation program under grant agreement No 727698, the Federal Ministry of Education and Research (01PL16003), and the University of Hohenheim.

Institutional Review Board Statement: Not applicable.

Informed Consent Statement: Not applicable.

Data Availability Statement: Data sets for this research are included in the references.

Acknowledgments: The authors are very grateful to Iris Lewandowski for making this work possible. Special thanks to Eva Lewin for the linguistic improvement of this study.

Conflicts of Interest: The authors declare that they have no known competing financial interest or personal relationships that could have appeared to influence the work reported in this paper. The funders had no role in the design of the study; in the collection, analyses, or interpretation of data; in the writing of the manuscript, or in the decision to publish the results. 


\section{Appendix A}

Table A1. Overview of growing season and meteorological conditions data from the field trial datasets used in this study.

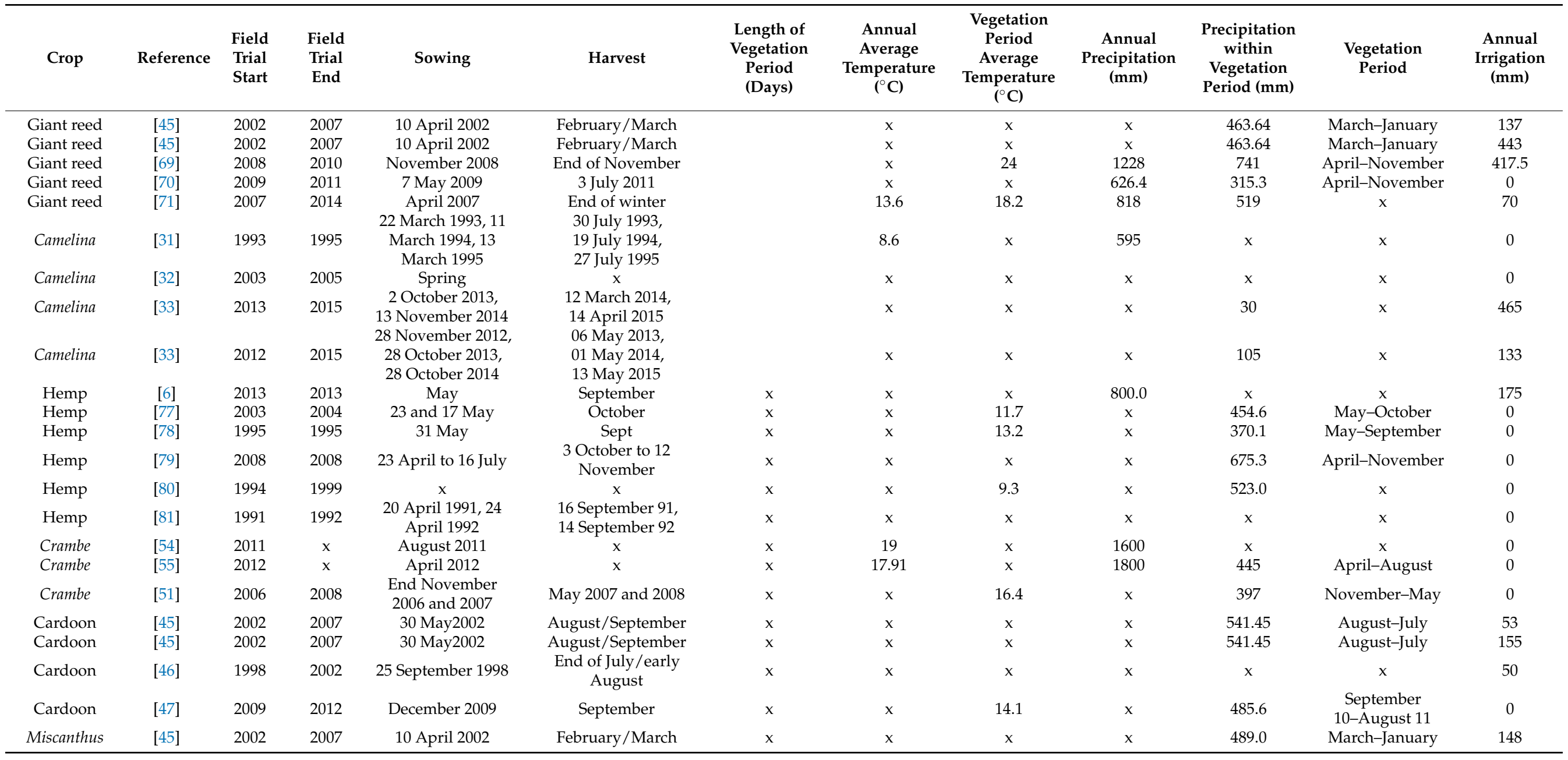


Table A1. Cont.

\begin{tabular}{|c|c|c|c|c|c|c|c|c|c|c|c|c|}
\hline Crop & Reference & $\begin{array}{l}\text { Field } \\
\text { Trial } \\
\text { Start }\end{array}$ & $\begin{array}{l}\text { Field } \\
\text { Trial } \\
\text { End }\end{array}$ & Sowing & Harvest & $\begin{array}{l}\text { Length of } \\
\text { Vegetation } \\
\text { Period } \\
\text { (Days) }\end{array}$ & $\begin{array}{c}\text { Annual } \\
\text { Average } \\
\text { Temperature } \\
\left({ }^{\circ} \mathrm{C}\right)\end{array}$ & $\begin{array}{c}\text { Vegetation } \\
\text { Period } \\
\text { Average } \\
\text { Temperature } \\
\left({ }^{\circ} \mathrm{C}\right) \\
\end{array}$ & $\begin{array}{c}\text { Annual } \\
\text { Precipitation } \\
\text { (mm) }\end{array}$ & $\begin{array}{l}\text { Precipitation } \\
\text { within } \\
\text { Vegetation } \\
\text { Period (mm) }\end{array}$ & $\begin{array}{l}\text { Vegetation } \\
\text { Period }\end{array}$ & $\begin{array}{l}\text { Annual } \\
\text { Irrigation } \\
(\mathrm{mm})\end{array}$ \\
\hline Miscanthus & [71] & 2007 & 2014 & April 2007 & End of winter & $\mathrm{x}$ & 13.6 & 18.2 & 818.0 & 519.0 & $\mathrm{x}$ & 70 \\
\hline Miscanthus & [85] & 1993 & 2012 & May 1993 & $\begin{array}{c}\mathrm{x} \\
12 \text { November, }\end{array}$ & $\mathrm{x}$ & 8.0 & $\mathrm{x}$ & 657.0 & $\mathrm{x}$ & 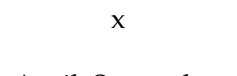 & 0 \\
\hline Miscanthus & [86] & 1997 & 1999 & 17 June & $\begin{array}{l}24 \text { November, } \\
18 \text { October } \\
27 \text { October, }\end{array}$ & $\mathrm{x}$ & 7.9 & 13.0 & 696.0 & 359.0 & April-September & 0 \\
\hline Miscanthus & [86] & 1997 & 1999 & 21 March & $\begin{array}{l}15 \text { October, } \\
6 \text { October }\end{array}$ & $\mathrm{x}$ & 15.4 & 19.6 & 665.0 & 156.0 & April-September & 396 \\
\hline Miscanthus & [87] & 1991 & 1995 & May 1991 & February 1995 & $\mathrm{x}$ & 10.5 & $\mathrm{x}$ & 801.0 & 576.0 & March-October & $\begin{array}{l}\text { First two } \\
\text { years }\end{array}$ \\
\hline Miscanthus & [87] & 1993 & 1995 & May 1993 & February 1995 & $x$ & 8.3 & $x$ & 988.0 & 687.0 & March-October & 0 \\
\hline Miscanthus & [88] & 2012 & 2013 & Spring 2012 & Early November 2013 & $\mathrm{x}$ & 9.2 & $\mathrm{x}$ & 1060.0 & $\mathrm{x}$ & $\begin{array}{c}\mathrm{x} \\
\text { April-September } \\
\text { 2012-2015, } \\
\text { (Lewandowski }\end{array}$ & $\mathrm{x}$ \\
\hline Miscanthus & [89] & 2012 & 2015 & 18 May 2012 & February-April & $\mathrm{x}$ & 9.7 & 12.6 & 1038.0 & 475.0 & $\begin{array}{l}\text { et al. 2016: } \\
\text { annual temp. and } \\
\text { annual } \\
\text { precipitation) }\end{array}$ & 0 \\
\hline Miscanthus & [90] & 2016 & 2017 & $\mathrm{x}$ & $\begin{array}{l}\text { Mid-September to } \\
\text { mid-October } 2016 \text { and } \\
2017\end{array}$ & $\mathrm{x}$ & 10.0 & $\mathrm{x}$ & 830.0 & $\mathrm{x}$ & 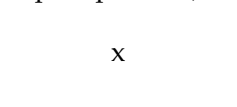 & 0 \\
\hline Miscanthus & [91] & 1994 & 1997 & $\mathrm{x}$ & $\begin{array}{c}\mathrm{x} \\
11 \text { November, }\end{array}$ & $\mathrm{x}$ & 9.5 & $\mathrm{x}$ & 603.0 & $\mathrm{x}$ & $\mathrm{x}$ & 0 \\
\hline Miscanthus & [86] & 1997 & 1999 & 21 May & $\begin{array}{l}23 \text { November, } \\
21 \text { November }\end{array}$ & $\mathrm{x}$ & 7.9 & 13.3 & 687.0 & 425.0 & April-September & 0 \\
\hline Miscanthus & [87] & 1992 & 1995 & May 1992 & February 1995 & $\mathrm{x}$ & 9.7 & $\mathrm{x}$ & 779.0 & 599.0 & March-October & In first Year \\
\hline Miscanthus & [92] & 2007 & 2010 & Spring 2007, $20 \mathrm{~cm}$ & $\begin{array}{l}\text { February-March 2009; } \\
\text { February } 2010\end{array}$ & $\mathrm{x}$ & 9.3 & $\mathrm{x}$ & 630.0 & $\mathrm{x}$ & $\mathrm{x}$ & 0 \\
\hline Switchgrass & [92] & 2007 & 2010 & Spring 2007, $20 \mathrm{~cm}$ & $\begin{array}{l}\text { February-March 2009; } \\
\text { February } 2010\end{array}$ & $\mathrm{x}$ & 9.3 & $\mathrm{x}$ & 630 & $\mathrm{x}$ & $\mathrm{x}$ & 0 \\
\hline Switchgrass & [105] & 2009 & 2012 & 2006 & Early October & $\begin{array}{l}150 \text { days } \\
\text { freeze-free } \\
\text { growing } \\
\text { season }\end{array}$ & $\mathrm{x}$ & $\mathrm{x}$ & $\mathrm{x}$ & 699 & March-October & 0 \\
\hline
\end{tabular}


Table A1. Cont.

\begin{tabular}{|c|c|c|c|c|c|c|c|c|c|c|c|c|}
\hline Crop & Reference & $\begin{array}{l}\text { Field } \\
\text { Trial } \\
\text { Start }\end{array}$ & $\begin{array}{l}\text { Field } \\
\text { Trial } \\
\text { End }\end{array}$ & Sowing & Harvest & $\begin{array}{l}\text { Length of } \\
\text { Vegetation } \\
\text { Period } \\
\text { (Days) }\end{array}$ & $\begin{array}{c}\text { Annual } \\
\text { Average } \\
\text { Temperature } \\
\left({ }^{\circ} \mathrm{C}\right)\end{array}$ & $\begin{array}{c}\text { Vegetation } \\
\text { Period } \\
\text { Average } \\
\text { Temperature } \\
\left({ }^{\circ} \mathrm{C}\right)\end{array}$ & $\begin{array}{c}\text { Annual } \\
\text { Precipitation } \\
\text { (mm) }\end{array}$ & $\begin{array}{l}\text { Precipitation } \\
\text { within } \\
\text { Vegetation } \\
\text { Period (mm) }\end{array}$ & $\begin{array}{l}\text { Vegetation } \\
\text { Period }\end{array}$ & $\begin{array}{l}\text { Annual } \\
\text { Irrigation } \\
(\mathrm{mm})\end{array}$ \\
\hline Switchgrass & [105] & 2009 & 2012 & 2006 & Early October & $\begin{array}{l}150 \text { days } \\
\text { freeze-free } \\
\text { growing } \\
\text { season }\end{array}$ & $\mathrm{x}$ & $\mathrm{x}$ & $\mathrm{x}$ & 698 & March-October & 0 \\
\hline Switchgrass & [114] & 2012 & 2016 & 2008 & 7 October & $\mathrm{x}$ & 5.8 & $x$ & 451.1 & $x$ & $\mathrm{x}$ & $\begin{array}{c}0 \\
150 \text { (in }\end{array}$ \\
\hline Switchgrass & [125] & 2012 & 2015 & May 2012 & Post-frost & $\mathrm{x}$ & 5.9 & $x$ & 704 & 512 & May-October & $\begin{array}{l}\text { establishment } \\
\text { year) }\end{array}$ \\
\hline Switchgrass & [125] & 2012 & 2015 & May 2012 & Post-frost & $x$ & 5.9 & $x$ & 704 & 512 & May-October & $\begin{array}{c}150 \text { (in } \\
\text { establishment } \\
\text { year) }\end{array}$ \\
\hline Switchgrass & [71] & 2007 & 2014 & April 2007 & End of winter & $\mathrm{x}$ & 13.6 & 18.2 & 818 & 519 & $\mathrm{x}$ & 70 \\
\hline Switchgrass & [126] & 2008 & 2011 & May 2009 & September/October 2010 & $\mathrm{x}$ & $\mathrm{x}$ & $\mathrm{x}$ & 177 & $\mathrm{x}$ & $\mathrm{x}$ & 120 \\
\hline Switchgrass & {$[88]$} & 2012 & 2013 & Spring 2012 & Early November 2013 & $x$ & 9.2 & $\mathrm{x}$ & 1060 & $x$ & $\mathrm{x}$ & $x$ \\
\hline $\begin{array}{l}\text { Reed canary } \\
\text { grass }\end{array}$ & [105] & 2009 & 2012 & 2006 & $\begin{array}{l}\text { Early July and early } \\
\text { October }\end{array}$ & $\begin{array}{l}150 \text { days } \\
\text { freeze-free } \\
\text { growing } \\
\text { season }\end{array}$ & $\mathrm{x}$ & $x$ & $\mathrm{x}$ & 698 & March-October & 0 \\
\hline $\begin{array}{l}\text { Reed canary } \\
\text { grass }\end{array}$ & [105] & 2009 & 2012 & 2006 & $\begin{array}{l}\text { Early July and early } \\
\text { October }\end{array}$ & $\begin{array}{l}151 \text { days } \\
\text { freeze-free } \\
\text { growing } \\
\text { season }\end{array}$ & $\mathrm{x}$ & $x$ & $x$ & 699 & March-October & 0 \\
\hline $\begin{array}{l}\text { Reed canary } \\
\text { grass }\end{array}$ & [6] & 2012 & 2015 & May 2012 & $\begin{array}{c}2012 \text { (August and } \\
\text { October), } 2013 \text { (May, } \\
\text { August, and October), } \\
2014 \text { (May, July, August, } \\
\text { October), } 2015 \text { (May, } \\
\text { October) }\end{array}$ & $x$ & $\mathrm{x}$ & $\mathrm{x}$ & 1000 & $x$ & $x$ & $20-50$ \\
\hline $\begin{array}{l}\text { Reed canary } \\
\text { grass }\end{array}$ & [6] & 2012 & 2015 & May 2012 & $\begin{array}{l}2012 \text { (August and } \\
\text { October), } 2013 \text { (May, } \\
\text { August, and October), } \\
2014 \text { (May, July, August, } \\
\text { October), } 2015 \text { (May, } \\
\text { October) }\end{array}$ & $x$ & $\mathrm{x}$ & $x$ & 800 & $x$ & $x$ & 150-200 \\
\hline
\end{tabular}


Table A1. Cont.

\begin{tabular}{|c|c|c|c|c|c|c|c|c|c|c|c|c|}
\hline Crop & Reference & $\begin{array}{l}\text { Field } \\
\text { Trial } \\
\text { Start }\end{array}$ & $\begin{array}{l}\text { Field } \\
\text { Trial } \\
\text { End }\end{array}$ & Sowing & Harvest & $\begin{array}{l}\text { Length of } \\
\text { Vegetation } \\
\text { Period } \\
\text { (Days) }\end{array}$ & $\begin{array}{c}\text { Annual } \\
\text { Average } \\
\text { Temperature } \\
\left({ }^{\circ} \mathrm{C}\right)\end{array}$ & $\begin{array}{c}\text { Vegetation } \\
\text { Period } \\
\text { Average } \\
\text { Temperature } \\
\left({ }^{\circ} \mathrm{C}\right)\end{array}$ & $\begin{array}{c}\text { Annual } \\
\text { Precipitation } \\
\text { (mm) }\end{array}$ & $\begin{array}{l}\text { Precipitation } \\
\text { within } \\
\text { Vegetation } \\
\text { Period (mm) }\end{array}$ & $\begin{array}{l}\text { Vegetation } \\
\text { Period }\end{array}$ & $\begin{array}{l}\text { Annual } \\
\text { Irrigation } \\
(\mathrm{mm})\end{array}$ \\
\hline $\begin{array}{l}\text { Reed canary } \\
\text { grass }\end{array}$ & [106] & 2012 & 2014 & 24 May 2012 & $\begin{array}{c}2013 \text { (4-7 June, } \\
\text { 29-31 July, 24-23 } \\
\text { September), 2014 } \\
\text { (27-29 June, 29-31 July, } \\
\text { 18 September) (A cut } \\
\text { took place at the end of } \\
\text { the } 2012 \text { growth period) }\end{array}$ & $\mathrm{x}$ & $\mathrm{x}$ & 12.2 & $\mathrm{x}$ & 370 & $\begin{array}{l}\text { March- } \\
\text { September }\end{array}$ & 0 \\
\hline $\begin{array}{l}\text { Reed canary } \\
\text { grass }\end{array}$ & [106] & 2012 & 2014 & 24 May 2012 & $\begin{array}{c}\text { 2013 (4-7 June, } \\
\text { 29-31 July, } \\
\text { 24-23 September), } \\
2014 \text { (27-29 June, } \\
29-31 \text { July, } \\
\text { 18 September) }\end{array}$ & $\mathrm{x}$ & $\mathrm{x}$ & 12.2 & $\mathrm{x}$ & 370 & $\begin{array}{l}\text { March- } \\
\text { September }\end{array}$ & 0 \\
\hline $\begin{array}{l}\text { Reed canary } \\
\text { grass }\end{array}$ & [92] & 2007 & 2009 & Spring 2007, $20 \mathrm{~cm}$ & $\begin{array}{l}\text { November-December 08; } \\
\text { Oct } 09\end{array}$ & $\mathrm{x}$ & 9.3 & $\mathrm{x}$ & 630 & $\mathrm{x}$ & $\mathrm{x}$ & 0 \\
\hline $\begin{array}{l}\text { Reed canary } \\
\text { grass }\end{array}$ & [107] & 1996 & 1997 & 25 & $\begin{array}{c}3 \text { cut (6-9 June, } \\
\text { 22-23 July, } \\
13 \text { September } / 13 \\
\text { October }\end{array}$ & $\mathrm{x}$ & $\mathrm{x}$ & 16 & $\mathrm{x}$ & 494 & May-October & 0 \\
\hline Poplar & [96] & 2010 & 2012 & $\begin{array}{l}\text { March 2010, } 22 \mathrm{~cm} \\
\text { long and 1.5-2 cm } \\
\text { diameter }\end{array}$ & March 2012 & $\mathrm{x}$ & $\mathrm{x}$ & & 530 & $\mathrm{x}$ & $\mathrm{x}$ & $\begin{array}{l}\text { In first Year } \\
175\end{array}$ \\
\hline Poplar & [95] & 2003 & 2007 & Spring 2003 & 2005 and 2007 & $\mathrm{x}$ & 13.6 & $\mathrm{x}$ & 639.5 & 189 & May-August & 70 \\
\hline Poplar & [71] & 2007 & 2014 & April 2007 & End of years 2, 4, 6 & $\mathrm{x}$ & 13.6 & 18.2 & 818 & 519 & May-August & $\begin{array}{c}70 \\
\text { In the dry }\end{array}$ \\
\hline Poplar & [97] & 2006 & 2014 & $\begin{array}{l}\text { March 2006, } \\
25 \mathrm{~cm} \text { long }\end{array}$ & $\begin{array}{c}\text { End of years 2008, } 2011 \\
\text { and } 2014\end{array}$ & $\mathrm{x}$ & 10.4 & $\mathrm{x}$ & 494 & $\mathrm{x}$ & $\mathrm{x}$ & $\begin{array}{l}\text { months } \\
\text { May to } \\
\text { September }\end{array}$ \\
\hline Poplar & [80] & 1994 & 1999 & $\mathrm{x}$ & $\begin{array}{c}\text { Two-year rotation cycle } \\
(1995 / 1996), \\
(1997 / 1998),(1999 / 2000)\end{array}$ & $\mathrm{x}$ & 9.3 & $\mathrm{x}$ & 523 & $\mathrm{x}$ & $\mathrm{x}$ & 0 \\
\hline Poplar & [98] & 2010 & 2013 & Early April 2010 & December 2013 & $\mathrm{x}$ & 7.7 & 13.85 & 694 & 521 & May-October & 0 \\
\hline Poplar & [101] & 2010 & 2014 & 7-10 April 2010 & February 2012, 2014 & $\mathrm{x}$ & 10 & 14 & 730 & 430 & $\mathrm{x}$ & 0 \\
\hline Willow & [128] & 1995 & 2000 & Spring 1995 & $\begin{array}{l}\text { November 1997, } \\
\text { November } 2000\end{array}$ & $\begin{array}{l}182 \text { frost-free } \\
\text { days }\end{array}$ & 6.4 & 17 & 954 & 427 & May-September & 0 \\
\hline
\end{tabular}


Table A1. Cont.

\begin{tabular}{|c|c|c|c|c|c|c|c|c|c|c|c|c|}
\hline Crop & Reference & $\begin{array}{l}\text { Field } \\
\text { Trial } \\
\text { Start }\end{array}$ & $\begin{array}{l}\text { Field } \\
\text { Trial } \\
\text { End }\end{array}$ & Sowing & Harvest & $\begin{array}{l}\text { Length of } \\
\text { Vegetation } \\
\text { Period } \\
\text { (Days) }\end{array}$ & $\begin{array}{c}\text { Annual } \\
\text { Average } \\
\text { Temperature } \\
\left({ }^{\circ} \mathrm{C}\right)\end{array}$ & $\begin{array}{c}\text { Vegetation } \\
\text { Period } \\
\text { Average } \\
\text { Temperature } \\
\left({ }^{\circ} \mathrm{C}\right)\end{array}$ & $\begin{array}{c}\text { Annual } \\
\text { Precipitation } \\
\text { (mm) }\end{array}$ & $\begin{array}{l}\text { Precipitation } \\
\text { within } \\
\text { Vegetation } \\
\text { Period }(\mathrm{mm})\end{array}$ & $\begin{array}{l}\text { Vegetation } \\
\text { Period }\end{array}$ & $\begin{array}{l}\text { Annual } \\
\text { Irrigation } \\
(\mathrm{mm})\end{array}$ \\
\hline Willow & [129] & 2007 & 2013 & Spring 2007, $25 \mathrm{~cm}$ & $\begin{array}{l}\text { Coppiced at the end of } \\
\text { the first growing season, } \\
\text { and first-rotation } \\
\text { biomass was harvested } \\
3 \text { years later }\end{array}$ & 112 & 2 & $\mathrm{x}$ & 375 & $\mathrm{x}$ & $\mathrm{x}$ & 0 \\
\hline Willow & [128] & 1995 & 2000 & Spring 1995 & $\begin{array}{l}\text { November 1997, } \\
\text { November } 2001\end{array}$ & $\begin{array}{l}182 \text { frost-free } \\
\text { days }\end{array}$ & 6.4 & 17 & 954 & 427 & May-September & 0 \\
\hline Willow & [131] & 2012 & 2014 & Spring 2011 & $\begin{array}{l}2014 \text { (cut back in } \\
\text { fall 2011) }\end{array}$ & $\mathrm{x}$ & 3.7 & 15.2 & 810 & 465 & May-September & 0 \\
\hline Willow & [131] & 2012 & 2014 & $\begin{array}{l}\text { Spring } 2012 \text { (due to } \\
\text { high mortality at } \\
\text { the first planting in } \\
2011 \text { had to be } \\
\text { planted again) }\end{array}$ & 2014 & $\mathrm{x}$ & 1.5 & 13.7 & 714 & 423 & May-September & 0 \\
\hline Willow & [131] & 2012 & 2014 & Spring 2011 & $\begin{array}{l}2014 \text { (cut back in } \\
\text { fall 2011) }\end{array}$ & $\mathrm{x}$ & 7.3 & 17.9 & 952 & 468 & May-September & 0 \\
\hline Willow & [131] & 2012 & 2014 & Spring 2012 & $\begin{array}{l}2014 \text { (cut back in } \\
\text { fall 2011) }\end{array}$ & $\mathrm{x}$ & 5.4 & 15.7 & 728 & 383 & May-September & 0 \\
\hline Willow & [71] & 2007 & 2014 & April 2007 & $\begin{array}{c}\text { End of year 2, 4, } 6 \\
\text { Two-year rotation cycle }\end{array}$ & $\mathrm{x}$ & 13.6 & 18.2 & 818 & 519 & $\mathrm{x}$ & 70 \\
\hline Willow & [80] & 1994 & 1999 & $\mathrm{x}$ & $\begin{array}{c}(1995 / 1996), \\
(1997 / 1998),(1999 / 2000)\end{array}$ & $\mathrm{x}$ & $\mathrm{x}$ & 9.3 & $\mathrm{x}$ & 523 & $\mathrm{x}$ & 0 \\
\hline Willow & [98] & 2010 & 2013 & $\begin{array}{l}\text { Early April 2010, at } \\
25 \mathrm{~cm} \text { length and } \\
0.9-1.1 \mathrm{~cm} \text { diameter }\end{array}$ & December 2013 & $x$ & 7.7 & 13.85 & 694 & 521 & May-October & 0 \\
\hline Willow & [127] & 2008 & 2012 & 20-21 April 2008 & $\begin{array}{l}\text { Early January 2012; end } \\
\text { of } 2008 \text { vegetation } \\
\text { period was harvested to } \\
\text { increase the number } \\
\text { of shoots }\end{array}$ & $\mathrm{x}$ & 7.8 & $x$ & 650 & $\mathrm{x}$ & $\mathrm{x}$ & 0 \\
\hline Willow & [132] & 2010 & 2012 & 5 May 2010, $20 \mathrm{~cm}$ & $\begin{array}{l}13 \text { November } 2012 \\
19 \text { November } 2012\end{array}$ & $x$ & 8 & 13.9 & 896 & 503 & May-September & 0 \\
\hline Willow & [132] & 2010 & 2012 & 21 May 2010, $20 \mathrm{~cm}$ & $\begin{array}{l}\text { (cut-back after first } \\
\text { growth year) }\end{array}$ & $\mathrm{x}$ & 7.8 & 13.8 & 596 & 320 & May-September & 0 \\
\hline Willow & [132] & 2010 & 2012 & $\begin{array}{c}\text { 10-17 May 2010, } \\
20 \mathrm{~cm}\end{array}$ & 11 February 2013 & $\mathrm{x}$ & 7.5 & 13.6 & 673 & 341 & May-September & 0 \\
\hline Willow & [132] & 2010 & 2012 & 10 May $2010,20 \mathrm{~cm}$ & 5 February 2013 & $\mathrm{x}$ & 8.1 & 14.5 & 858 & 453 & May-September & 0 \\
\hline
\end{tabular}


Table A1. Cont.

\begin{tabular}{|c|c|c|c|c|c|c|c|c|c|c|c|c|}
\hline Crop & Reference & $\begin{array}{l}\text { Field } \\
\text { Trial } \\
\text { Start }\end{array}$ & $\begin{array}{l}\text { Field } \\
\text { Trial } \\
\text { End }\end{array}$ & Sowing & Harvest & $\begin{array}{l}\text { Length of } \\
\text { Vegetation } \\
\text { Period } \\
\text { (Days) }\end{array}$ & $\begin{array}{c}\text { Annual } \\
\text { Average } \\
\text { Temperature } \\
\left({ }^{\circ} \mathrm{C}\right)\end{array}$ & $\begin{array}{c}\text { Vegetation } \\
\text { Period } \\
\text { Average } \\
\text { Temperature } \\
\left({ }^{\circ} \mathrm{C}\right)\end{array}$ & $\begin{array}{c}\text { Annual } \\
\text { Precipitation } \\
\text { (mm) }\end{array}$ & $\begin{array}{c}\text { Precipitation } \\
\text { within } \\
\text { Vegetation } \\
\text { Period (mm) }\end{array}$ & $\begin{array}{l}\text { Vegetation } \\
\text { Period }\end{array}$ & $\begin{array}{c}\text { Annual } \\
\text { Irrigation } \\
(\mathrm{mm})\end{array}$ \\
\hline Willow & [133] & 2010 & 2011 & 2010 & Early December 2011 & $\mathrm{x}$ & $\mathrm{x}$ & $\mathrm{x}$ & $\mathrm{x}$ & $\mathrm{x}$ & $\mathrm{x}$ & 0 \\
\hline Willow & [133] & 2010 & 2011 & 2010 & Early December 2011 & $\mathrm{x}$ & $\mathrm{x}$ & $\mathrm{x}$ & $\mathrm{x}$ & $\mathrm{x}$ & $\mathrm{x}$ & 0 \\
\hline Willow & [92] & 2007 & 2010 & Spring 2007 & $\begin{array}{c}\text { January 2008, December } \\
\text { 2009-February } 2010\end{array}$ & $x$ & 9.3 & $x$ & 630 & $\mathrm{x}$ & $\mathrm{x}$ & 0 \\
\hline Willow & [132] & 2010 & 2012 & 6 May 2010 & 13 November 2012 & $\mathrm{x}$ & 8 & 13.9 & 896 & 503 & May-September & 0 \\
\hline Cup plant & {$[62]$} & 2016 & 2017 & 2016 & October 2017 & $\hat{x}$ & 9 & $x$ & 768 & $\mathrm{x}$ & $\mathrm{x}$ & 0 \\
\hline Cup plant & {$[60]$} & 2014 & 2015 & 2014 & Early September 2015 & $\mathrm{x}$ & $\mathrm{x}$ & 14.5 & $\mathrm{x}$ & 356 & $\begin{array}{c}\text { March- } \\
\text { September }\end{array}$ & 0 \\
\hline Cup plant & [60] & 2014 & 2015 & 2014 & Early September 2015 & $\mathrm{x}$ & $\mathrm{x}$ & 13.6 & $\mathrm{x}$ & 383 & $\begin{array}{l}\text { March- } \\
\text { September }\end{array}$ & 0 \\
\hline Cup plant & [63] & 2016 & 2018 & May 16 & $\begin{array}{c}\text { Early October } 2017 \\
\text { and } 2018\end{array}$ & $\mathrm{x}$ & 8.2 & 16 & 536 & 434 & April-October & 0 \\
\hline Cup plant & [64] & 2012 & 2013 & $\mathrm{x}$ & $\mathrm{x}$ & $\mathrm{x}$ & $\mathrm{x}$ & $x$ & $x$ & $\mathrm{x}$ & $\mathrm{x}$ & 215 \\
\hline Sorghum & [113] & 2013 & 2014 & $\begin{array}{l}7 \text { May 2013, } \\
12 \text { May } 2014\end{array}$ & September & $\begin{array}{c}\text { Frost-free } \\
\text { period } \\
130-160\end{array}$ & 6.2 & $x$ & 348.3 & $\mathrm{x}$ & $\mathrm{x}$ & 156 \\
\hline Sorghum & [114] & 2012 & 2013 & 7 May & 7 October & $\mathrm{x}$ & 5.8 & $\mathrm{x}$ & 451.1 & $\mathrm{x}$ & $\mathrm{x}$ & 0 \\
\hline Sorghum & [115] & 2009 & 2010 & $\begin{array}{l}4 \text { June 2009, } \\
24 \text { May } 2010\end{array}$ & $\begin{array}{l}22 \text { August 2009, } \\
19 \text { August } 2010\end{array}$ & $\mathrm{x}$ & 17.1 & 27 & 594 & 255 & May-August & 219 \\
\hline Sorghum & [116] & 2012 & 2012 & 5 June & 14 August & $\mathrm{x}$ & $\mathrm{x}$ & $x$ & 20 & $\mathrm{x}$ & $\mathrm{x}$ & Yes \\
\hline
\end{tabular}




\section{References}

1. Gerwin, W.; Repmann, F.; Galatsidas, S.; Vlachaki, D.; Gounaris, N.; Baumgarten, W.; Volkmann, C.; Keramitzis, D.; Kiourtsis, F.; Freese, D. Assessment and Quantification of Marginal Lands for Biomass Production in Europe Using Soil-Quality Indicators. Soil 2018, 4, 267-290. [CrossRef]

2. Von Cossel, M.; Iqbal, Y.; Scordia, D.; Cosentino, S.L.; Elbersen, B.; Staritsky, I.; Van Eupen, M.; Mantel, S.; Prysiazhniuk, O.; Maliarenko, O.; et al. Low-Input Agricultural Practices for Industrial Crops on Marginal Land; University of Hohenheim: Stuttgart, Germany, 2018. [CrossRef]

3. Rossiter, D.; Schulte, R.; van Velthuizen, H.; Le-Bas, C.; Nachtergaele, F.; Jones, R.; van Orshoven, J. Updated Common Bio-Physical Criteria to Define Natural Constraints for Agriculture in Europe; Terres, J., Toth, T., Van Orshoven, J., Eds.; EUR, Scientific and Technical Research Series; Publications Office: Luxembourg, 2014; Volume 26638, ISBN 92-79-38190-3.

4. Scheffer, F.; Schachtschabel, P.; Blume, H.-P.; Brümmer, G.W.; Horn, R.; Kandeler, E.; Kögel-Knabner, I.; Kretzschmar, R.; Stahr, K.; Thiele-Bruhn, S.; et al. 16. Auflage. In Lehrbuch der Bodenkunde; Spektrum Akademischer Verlag: Heidelberg, Germany, 2010; ISBN 978-3-8274-1444-1.

5. Confalonieri, R.; Jones, B.; Van Diepen, K.; Van Orshoven, J. Scientific Contribution on Combining Biophysical Criteria Underpinning the Delineation of Agricultural Areas Affected by Specific Constraints. In Methodology and Factsheets for Plausible Criteria Combinations; Terres, J., Hagyo, A., Wania, A., Eds.; JRC Publications Office: Luxembourg, 2014. [CrossRef]

6. Manevski, K.; Lærke, P.E.; Jiao, X.; Santhome, S.; Jørgensen, U. Biomass Productivity and Radiation Utilisation of Innovative Cropping Systems for Biorefinery. Agric. For. Meteorol. 2017, 233, 250-264. [CrossRef]

7. Jahn, R.; Blume, H.P.; Asio, V.B.; Spaargaren, O.; Schad, P. Guidelines for Soil Description, 4th ed.; FAO: Rome, Italy, 2006; ISBN 978-92-5-105521-2.

8. Ramirez-Almeyda, J.; Elbersen, B.; Monti, A.; Staritsky, I.; Panoutsou, C.; Alexopoulou, E.; Schrijver, R.; Elbersen, W. Chapter 9-Assessing the Potentials for Nonfood Crops. In Modeling and Optimization of Biomass Supply Chains; Panoutsou, C., Ed.; Academic Press: Cambridge, MA, USA, 2017; pp. 219-251, ISBN 978-0-12-812303-4.

9. Dahmen, N.; Lewandowski, I.; Zibek, S.; Weidtmann, A. Integrated Lignocellulosic Value Chains in a Growing Bioeconomy: Status Quo and Perspectives. GCB Bioenergy 2019, 11, 107-117. [CrossRef]

10. Lange, L.; Connor, K.O.; Arason, S.; Bundgård-Jørgensen, U.; Canalis, A.; Carrez, D.; Gallagher, J.; Gøtke, N.; Huyghe, C.; Jarry, B.; et al. Developing a Sustainable and Circular Bio-Based Economy in EU: By Partnering Across Sectors, Upscaling and Using New Knowledge Faster, and For the Benefit of Climate, Environment \& Biodiversity, and People \& Business. Front. Bioeng. Biotechnol. 2021, 8, 1456. [CrossRef]

11. Panoutsou, C.; Singh, A. A Value Chain Approach to Improve Biomass Policy Formation. GCB Bioenergy 2020, 12, 464-475. [CrossRef]

12. Fernando, A.L.; Rettenmaier, N.; Soldatos, P.; Panoutsou, C. Sustainability of Perennial Crops Production for Bioenergy and Bioproducts. In Perennial Grasses for Bioenergy and Bioproducts; Alexopoulou, E., Ed.; Academic Press: Cambridge, MA, USA, 2018; pp. 245-283, ISBN 978-0-12-812900-5.

13. Ferreira, J.A.; Brancoli, P.; Agnihotri, S.; Bolton, K.; Taherzadeh, M.J. A Review of Integration Strategies of Lignocelluloses and Other Wastes in 1st Generation Bioethanol Processes. Process. Biochem. 2018, 75, 173-186. [CrossRef]

14. Ubando, A.T.; Felix, C.B.; Chen, W.-H. Biorefineries in Circular Bioeconomy: A Comprehensive Review. Bioresour. Technol. 2020, 299, 122585. [CrossRef]

15. Vogelpohl, T. Transnational Sustainability Certification for the Bioeconomy? Patterns and Discourse Coalitions of Resistance and Alternatives in Biomass Exporting Regions. Energy Sustain. Soc. 2021, 11, 3. [CrossRef]

16. Baum, G. Betriebswirtschaftliche Betrachtung der Wildpflanzennutzung für Biogasbetriebe 2019. Available online: https://baden-wuerttemberg.nabu.de/imperia/md/content/badenwuerttemberg/vortraege/baum_betriebswirtschaftl_ wildpflanzen_f__r_biogas_ver_ffentlichung.pdf (accessed on 23 November 2021).

17. Winkler, B.; Mangold, A.; Von Cossel, M.; Clifton-Brown, J.; Pogrzeba, M.; Lewandowski, I.; Iqbal, Y.; Kiesel, A. Implementing Miscanthus into Farming Systems: A Review of Agronomic Practices, Capital and Labour Demand. Renew. Sustain. Energy Rev. 2020, 132, 110053. [CrossRef]

18. Haberzettl, J.; Hilgert, P.; Von Cossel, M. A Critical Review on Lignocellulosic Biomass Yield Modeling and the Bioenergy Potential from Marginal Land. Agronomy 2021, 11. (in press).

19. BMEL. Agrarexporte Verstehen-Fakten Und Hintergründe; BMEL: Berlin, Germany, 2018. Available online: https://www.bmel.de/ SharedDocs/Downloads/DE/Broschueren/Agrarexporte-verstehen.pdf;jsessionid=A391E0A1B2016894D23176E8A8D57E2E. internet2852?_blob=publicationFile\&v $=5$ (accessed on 23 November 2021).

20. UBA (Umweltbundesamt). Toward Ecofriendly Farming. Available online: https://www.umweltbundesamt.de/en/topics/soilagriculture/toward-ecofriendly-farming (accessed on 20 October 2021).

21. European Commission CORDIS EU Research Results. Available online: https://cordis.europa.eu/projects/en (accessed on 23 November 2021).

22. Elsevier. How Can I Best Use the Advanced Search? Available online: https://service.elsevier.com/app/answers/detail/a_id/ 11365 / c/10546/supporthub/scopus / (accessed on 20 October 2021). 
23. von Cossel, M.; Lewandowski, I.; Elbersen, B.; Staritsky, I.; Van Eupen, M.; Iqbal, Y.; Mantel, S.; Scordia, D.; Testa, G.; Cosentino, S.L.; et al. Marginal Agricultural Land Low-Input Systems for Biomass Production. Energies 2019, 12, 3123. [CrossRef]

24. Moser, B.R. Camelina (Camelina sativa L.) Oil as a Biofuels Feedstock: Golden Opportunity or False Hope? Lipid Technol. 2010, 22, 270-273. [CrossRef]

25. Panacea. Scientific Papers and Training Materials-Panacea. Summary Factsheet Camelina Sativa; Agricultural University of Athens: Athens, Greece, 2020; Available online: http://www.panacea-h2020.eu/wp-content/uploads/2019/10/SUMMARYFACTSHEET_camelina.pdf (accessed on 20 October 2021).

26. Panacea. Scientific Papers and Training Materials-Panacea. Summary Factsheet HEAR; Agricultural University of Athens: Athens, Greece, 2020; Available online: http:/ / www.panacea-h2020.eu/wp-content/uploads/2019/10/SUMMARY-FACTSHEET_HEAR. pdf (accessed on 20 October 2021).

27. Zubr, J. Oil-Seed Crop: Camelina Sativa. Ind. Crop. Prod. 1997, 6, 113-119. [CrossRef]

28. Vollmann, J.; Moritz, T.; Kargl, C.; Baumgartner, S.; Wagentristl, H. Agronomic Evaluation of Camelina Genotypes Selected for Seed Quality Characteristics. Ind. Crop. Prod. 2007, 26, 270-277. [CrossRef]

29. Krzyżaniak, M.; Stolarski, M.J.; Tworkowski, J.; Puttick, D.; Eynck, C.; Załuski, D.; Kwiatkowski, J. Yield and Seed Composition of 10 Spring Camelina Genotypes Cultivated in the Temperate Climate of Central Europe. Ind. Crop. Prod. 2019, 138, 111443. [CrossRef]

30. Zanetti, F.; Eynck, C.; Christou, M.; Krzyżaniak, M.; Righini, D.; Alexopoulou, E.; Stolarski, M.J.; Van Loo, E.N.; Puttick, D.; Monti, A. Agronomic Performance and Seed Quality Attributes of Camelina (Camelina sativa L. Crantz) in Multi-Environment Trials across Europe and Canada. Ind. Crop. Prod. 2017, 107, 602-608. [CrossRef]

31. Agegnehu, M.; Honermeier, B. Effects of Seeding Rates and Nitrogen Fertilization on Seed Yield, Seed Quality and Yield Components of False Flax (Camelina Sativa Crtz.). Die Bodenkult. 1997, 15, 1.

32. Paulsen, H.M. Organic mixed cropping systems with oilseeds 1 . Yields of mixed cropping systems of legumes or spring wheat with false flax (Camelina sativa L. Crantz). Landbauforsch. Völkenrode 2007, 57, 107-117.

33. George, N.; Hollingsworth, J.; Yang, W.-R.; Kaffka, S. Canola and Camelina as New Crop Options for Cool-Season Production in California. Crop. Sci. 2017, 57, 693-712. [CrossRef]

34. Von Cossel, M.; Wagner, M.; Lask, J.; Magenau, E.; Bauerle, A.; Von Cossel, V.; Warrach-Sagi, K.; Elbersen, B.; Staritsky, I.; van Eupen, M.; et al. Prospects of Bioenergy Cropping Systems for A More Social-Ecologically Sound Bioeconomy. Agronomy 2019, 9, 605. [CrossRef]

35. Zubr, J. Qualitative Variation of Camelina Sativa Seed from Different Locations. Ind. Crop. Prod. 2003, 17, 161-169. [CrossRef]

36. Zanetti, F.; Alberghini, B.; Marjanović Jeromela, A.; Grahovac, N.; Rajković, D.; Kiprovski, B.; Monti, A. Camelina, an Ancient Oilseed Crop Actively Contributing to the Rural Renaissance in Europe. A Review. Agron. Sustain. Dev. 2021, 41, 2. [CrossRef]

37. Boari, F.; Schiattone, M.I.; Calabrese, N.; Montesano, F.F.; Cantore, V. Effect of Nitrogen Management on Wild and Domestic Genotypes of Cardoon for Agro-Energy Purpose. Acta. Hortic. 2016, 15-22. [CrossRef]

38. Fernández, J.; Curt, M.D.; Aguado, P.L. Industrial Applications of Cynara cardunculus L. for Energy and Other Uses. Ind. Crop. Prod. 2006, 24, 222-229. [CrossRef]

39. Francaviglia, R.; Bruno, A.; Falcucci, M.; Farina, R.; Renzi, G.; Russo, D.E.; Sepe, L.; Neri, U. Yields and Quality of Cynara cardunculus L. Wild and Cultivated Cardoon Genotypes. A Case Study from a Marginal Land in Central Italy. Eur. J. Agron. 2016, 72, 10-19. [CrossRef]

40. Gominho, J.; Curt, M.D.; Lourenço, A.; Fernández, J.; Pereira, H. Cynara cardunculus L. as a Biomass and Multi-Purpose Crop: A Review of 30 Years of Research. Biomass Bioenergy 2018, 109, 257-275. [CrossRef]

41. Grammelis, P.; Malliopoulou, A.; Basinas, P.; Danalatos, N.G. Cultivation and Characterization of Cynara Cardunculus for Solid Biofuels Production in the Mediterranean Region. Int. J. Mol. Sci. 2008, 9, 1241-1258. [CrossRef]

42. Panoutsou, C.; Singh, A.; Christensen, T. D7.1-Good Practices; Zenodo: Genève, Switzerland, 2018. [CrossRef]

43. Foti, S.; Mauromicale, G.; Raccuia, S.A.; Fallico, B.; Fanella, F.; Maccarone, E. Possible Alternative Utilization of Cynara Spp.: I. Biomass, Grain Yield and Chemical Composition of Grain. Ind. Crop. Prod. 1999, 10, 219-228. [CrossRef]

44. Angelini, L.G.; Ceccarini, L.; Nassi o Di Nasso, N.; Bonari, E. Long-Term Evaluation of Biomass Production and Quality of Two Cardoon (Cynara cardunculus L.) Cultivars for Energy Use. Biomass Bioenergy 2009, 33, 810-816. [CrossRef]

45. Mantineo, M.; D’Agosta, G.M.; Copani, V.; Patanè, C.; Cosentino, S.L. Biomass Yield and Energy Balance of Three Perennial Crops for Energy Use in the Semi-Arid Mediterranean Environment. Field Crop. Res. 2009, 114, 204-213. [CrossRef]

46. Mauromicale, G.; Ierna, A. Biomass and Grain Yield in Cynar cardunculus L. Genotypes Grown in a Permanent Crop with Low Input. Acta Hortic. 2004, 593-598. [CrossRef]

47. Curt, M.D.; Mosquera, F.; Sanz, M.; Sánchez, J.; Sánchez, G.; Esteban, B.; Fernández, J. Effect of Land Slope on Biomass Production of Cynara cardunculus L. In Proceedings of the 20th EU Biomass Conference and Exhibition, Milan, Italy, 18-22 June 2012; pp. 186-190.

48. Ţîţei, V. The Evaluation of the Biomass Quality of Cardoon, Cynara Cardunculus, and Prospects of Its Use in Moldova. Sci. Papers. Ser. A Agron. 2019, 62, 159-166.

49. Zhu, L.-H. Crambe (Crambe abyssinica). In Industrial Oil Crops; McKeon, T., Hayes, D., Hildebrand, D., Weselake, R., Eds.; Elsevier Inc.: Cambridge, MA, USA, 2016; pp. 195-205, ISBN 978-1-893997-98-1. 
50. Krzyżaniak, M.; Stolarski, M.J. Life Cycle Assessment of Camelina and Crambe Production for Biorefinery and Energy Purposes. J. Clean. Prod. 2019, 237, 117755. [CrossRef]

51. Zanetti, F.; Scordia, D.; Vamerali, T.; Copani, V.; Dal Cortivo, C.; Mosca, G. Crambe Abyssinica a Non-Food Crop with Potential for the Mediterranean Climate: Insights on Productive Performances and Root Growth. Ind. Crop. Prod. 2016, 90, 152-160. [CrossRef]

52. Falasca, S.L.; Flores, N.; Lamas, M.C.; Carballo, S.M.; Anschau, A. Crambe Abyssinica: An Almost Unknown Crop with a Promissory Future to Produce Biodiesel in Argentina. Int. J. Hydrog. Energy 2010, 35, 5808-5812. [CrossRef]

53. Zoz, T.; Steiner, F.; Zoz, A.; Castagnara, D.D.; Witt, T.W.; Zanotto, M.D.; Auld, D.L. Effect of Row Spacing and Plant Density on Grain Yield and Yield Components of Crambe Abyssinica Hochst. SCA 2018, 39, 393. [CrossRef]

54. Rosa, H.A.; Secco, D.; Santos, R.F.; Ciotti de Marins, A.; Fornasari, C.H.; Veloso, G. Structuring potential of cover crops in a clayey oxisol and their effect on crambe grain yield and oil content. RSA 2018, 19, 160. [CrossRef]

55. Viana, O.H.; Santos, R.F.; de Oliveira, R.C.; Secco, D.; de Souza, S.N.M.; Tokura, L.K.; da Silva, T.R.B.; Gurgacz, F. Crambe ("Crambe Abyssinica" H.) Development and Productivity under Different Sowing Densities. Aust. J. Crop. Sci. 2015, 9, 690.

56. Krzyżaniak, M.; Stolarski, M.J.; Graban, Ł.; Lajszner, W.; Kuriata, T. Camelina and Crambe Oil Crops for Bioeconomy-Straw Utilisation for Energy. Energies 2020, 13, 1503. [CrossRef]

57. Stolarski, M.J.; Krzyżaniak, M.; Kwiatkowski, J.; Tworkowski, J.; Szczukowski, S. Energy and Economic Efficiency of Camelina and Crambe Biomass Production on a Large-Scale Farm in North-Eastern Poland. Energy 2018, 150, 770-780. [CrossRef]

58. Chrestensen, N.L. Anbauanleitung Für Die Durchwachsene Silphie (Silphium Perfoliatum). 2012. Available online: http:/ /www. rekulta.org/fileadmin/downloads/Ziel3-Projektstatus/2013_07_10_Feldtag/Silphie_Anbauanleitung_2013.pdf (accessed on 20 October 2021).

59. Gansberger, M.; Montgomery, L.F.R.; Liebhard, P. Botanical Characteristics, Crop Management and Potential of Silphium perfoliatum L. as a Renewable Resource for Biogas Production: A Review. Ind. Crop. Prod. 2015, 63, 362-372. [CrossRef]

60. Hartmann, A.; Lunenberg, T. Yield Potential of Cup Plant under Bavarian Cultivation Conditions. J. Fur Kult. 2016, 68, 385-388. [CrossRef]

61. Berendonk, C.; Dahlhoff, A.; Dickeduisberg, M.; Dissemond, A.; Erhardt, N.; Gruber, W.; Hartmann, H.-B.; Holz, J.; Jacobs, G.; Kasten, P.; et al. Nachwachsende Rohstoffe Vom Acker; Landwirtschaftskammer Nordrhein-Westfalen: Münster, Germany, 2012.

62. Facciotto, G.; Bury, M.; Chiocchini, F.; Cumplido Marín, L.; Czyż, H.; Graves, A.; Kitczak, T.; Martens, R.; Morhart, C.; Paris, P. Performance of Sida Hermaphrodita and Silphium Perfoliatum in Europe: Preliminary Results. Proceedings of 26th European Biomass Conference and Exhibition Proceedings, Copenhagen, Denmark, 14 May 2018; pp. 350-352. [CrossRef]

63. Siwek, H.; Włodarczyk, M.; Możdżer, E.; Bury, M.; Kitczak, T. Chemical Composition and Biogas Formation Potential of Sida Hermaphrodita and Silphium Perfoliatum. Appl. Sci. 2019, 9, 4016. [CrossRef]

64. Schittenhelm, S.; Schoo, B.; Schroetter, S. Yield physiology of biogas crops: Comparison of cup plant, maize, and lucerne-grass. J. Für Kult. 2016, 68, 378-384.

65. Laurent, A.; Pelzer, E.; Loyce, C.; Makowski, D. Ranking Yields of Energy Crops: A Meta-Analysis Using Direct and Indirect Comparisons. Renew. Sustain. Energy Rev. 2015, 46, 41-50. [CrossRef]

66. Scordia, D.; Testa, G.; Cosentino, S.L. Perennial Grasses as Lignocellulosic Feedstock for Second-Generation Bioethanol Production in Mediterranean Environment. Ital. J. Agron. 2014, 9, 84. [CrossRef]

67. Angelini, L.G.; Ceccarini, L.; Di Nassi o Nasso, N.; Bonari, E. Comparison of Arundo conax L. and Miscanthus $\times$ Giganteus in a Long-Term Field Experiment in Central Italy: Analysis of Productive Characteristics and Energy Balance. Biomass Bioenergy 2009, 33, 635-643. [CrossRef]

68. Pilu, R.; Manca, A.; Landoni, M. Arundo Donax as an Energy Crop: Pros and Cons of the Utilization of This Perennial Plant. Maydica 2013, 58, 54-59.

69. Erickson, J.E.; Soikaew, A.; Sollenberger, L.E.; Bennett, J.M. Water Use and Water-Use Efficiency of Three Perennial Bioenergy Grass Crops in Florida. Agriculture 2012, 2, 325-338. [CrossRef]

70. Di Nassi o Nasso, N.; Roncucci, N.; Bonari, E. Seasonal Dynamics of Aboveground and Belowground Biomass and Nutrient Accumulation and Remobilization in Giant Reed (Arundo donax L.): A Three-Year Study on Marginal Land. Bioenergy Res. 2013, 6, 725-736. [CrossRef]

71. Amaducci, S.; Facciotto, G.; Bergante, S.; Perego, A.; Serra, P.; Ferrarini, A.; Chimento, C. Biomass Production and Energy Balance of Herbaceous and Woody Crops on Marginal Soils in the Po Valley. GCB Bioenergy 2017, 9, 31-45. [CrossRef]

72. Impagliazzo, A.; Mori, M.; Fiorentino, N.; Di Mola, I.; Ottaiano, L.; Gianni, D.; Nocerino, S.; Fagnano, M. Crop Growth Analysis and Yield of a Lignocellulosic Biomass Crop (Arundo Donax L.) in Three Marginal Areas of Campania Region. Ital. J. Agron. 2017, 12, 755. [CrossRef]

73. Hanzhenko, O. Catalogue for Bioenergy Crops and Their Suitability in the Categories of MagLs; European Union: Brussels, Belgium, 2016; Available online: http:/ / seemla.eu/wp-content/uploads/2019/02/D2.2-Catalogue-for-bioenergy-crops-and-their-suitabilityin-the-categories-of-MagLs.pdf (accessed on 20 October 2021).

74. Parenti, A.; Lambertini, C.; Monti, A. Areas with Natural Constraints to Agriculture: Possibilities and Limitations for The Cultivation of Switchgrass (Panicum virgatum L.) and Giant Reed (Arundo donax L.) in Europe. In Land Allocation for Biomass Crops: Challenges and Opportunities with Changing Land Use; Li, R., Monti, A., Eds.; Springer International Publishing: Cham, Switzerland, 2018; pp. 39-63, ISBN 978-3-319-74536-7. 
75. Bócsa, I.; Karus, M.; Lohmeyer, D. Vollst. überarb. und erg. 2. Aufl. In Der Hanfanbau; Landwirtschaftsverlag: Münster-Hiltrup, Germany, 2000; ISBN 3-7843-3066-5.

76. Struik, P.C.; Amaducci, S.; Bullard, M.J.; Stutterheim, N.C.; Venturi, G.; Cromack, H.T.H. Agronomy of Fibre Hemp (Cannabis Sativa L.) in Europe. Ind. Crop. Prod. 2000, 11, 107-118. [CrossRef]

77. Pahkala, K.; Pahkala, E.; Syrjälä, H. Northern Limits to Fiber Hemp Production in Europe. J. Ind. Hemp 2008, 13, 104-116. [CrossRef]

78. Sankari, H.S.; Mela, T.J.N. Plant Development and Stem Yield of Non-Domestic Fibre Hemp (Cannabis Sativa L.) Cultivars in Long-Day Growth Conditions in Finland. J. Agron. Crop. Sci. 1998, 181, 153-159. [CrossRef]

79. Faux, A.-M.; Draye, X.; Lambert, R.; d'Andrimont, R.; Raulier, P.; Bertin, P. The Relationship of Stem and Seed Yields to Flowering Phenology and Sex Expression in Monoecious Hemp (Cannabis Sativa L.). Eur. J. Agron. 2013, 47, 11-22. [CrossRef]

80. Scholz, V. The Growth Productivity, and Environmental Impact of the Cultivation of Energy Crops on Sandy Soil in Germany. Biomass Bioenergy 2002, 23, 81-92. [CrossRef]

81. Van der Werf, H.M.G.; Wijlhuizen, M.; Schutter, J.A.A. Plant Density and Self-Thinning Affect Yield and Quality of Fibre Hemp (Cannabis Sativa L.). Field Crop. Res. 1995, 40, 153-164. [CrossRef]

82. Ranalli, P. Agronomical and Physiological Advances in Hemp Crops. In Advances in Hemp Research; CRC Press: Boca Raton, FL, USA, 1999; ISBN 978-0-429-07626-8.

83. Lewandowski, I.; CLIFTON-BROWN, J.C.; Scurlock, J.M.O.; Huisman, W. Miscanthus: European Experience with a Novel Energy Crop. Biomass Bioenergy 2000, 19, 209-227. [CrossRef]

84. Bufe, C.; Korevaar, H. Evaluation of Additional Crops for Dutch List of Ecological Focus Area; Wageningen Research Foundation (WR) Business Unit Agrosystems Research: Lelystad, The Netherlands, 2018; Volume 793.

85. Larsen, S.U.; Jørgensen, U.; Kjeldsen, J.B.; Lærke, P.E. Long-Term Miscanthus Yields Influenced by Location, Genotype, Row Distance, Fertilization and Harvest Season. Bioenergy Res. 2014, 7, 620-635. [CrossRef]

86. Clifton-Brown, J.C.; Lewandowski, I.; Andersson, B.; Basch, G.; Christian, D.G.; Kjeldsen, J.B.; Jørgensen, U.; Mortensen, J.V.; Riche, A.B.; Schwarz, K.-U. Performance of 15 Miscanthus Genotypes at Five Sites in Europe. Agron. J. 2001, 93, 1013-1019. [CrossRef]

87. Lewandowski, I.; Kicherer, A. Combustion Quality of Biomass: Practical Relevance and Experiments to Modify the Biomass Quality of Miscanthus x Giganteus. Eur. J. Agron. 1997, 6, 163-177. [CrossRef]

88. Saha, D.; Rau, B.M.; Kaye, J.P.; Montes, F.; Adler, P.R.; Kemanian, A.R. Landscape Control of Nitrous Oxide Emissions during the Transition from Conservation Reserve Program to Perennial Grasses for Bioenergy. GCB Bioenergy 2017, 9, 783-795. [CrossRef]

89. Kalinina, O.; Nunn, C.; Sanderson, R.; Hastings, A.F.S.; van der Weijde, T.; Özgüven, M.; Tarakanov, I.; Schüle, H.; Trindade, L.M.; Dolstra, O.; et al. Extending Miscanthus Cultivation with Novel Germplasm at Six Contrasting Sites. Front. Plant Sci. 2017,8 , 563. [CrossRef] [PubMed]

90. Mangold, A.; Lewandowski, I.; Möhring, J.; Clifton-Brown, J.; Krzyżak, J.; Mos, M.; Pogrzeba, M.; Kiesel, A. Harvest Date and Leaf:Stem Ratio Determine Methane Hectare Yield of Miscanthus Biomass. GCB Bioenergy 2019, 11, 21-33. [CrossRef]

91. Kahle, P.; Beuch, S.; Boelcke, B.; Leinweber, P.; Schulten, H.-R. Cropping of Miscanthus in Central Europe: Biomass Production and Influence on Nutrients and Soil Organic Matter. Eur. J. Agron. 2001, 15, 171-184. [CrossRef]

92. Lord, R.A. Reed Canarygrass (Phalaris arundinacea) Outperforms Miscanthus or Willow on Marginal Soils, Brownfield and Non-Agricultural Sites for Local, Sustainable Energy Crop Production. Biomass Bioenergy 2015, 78, 110-125. [CrossRef]

93. Lewandowski, I.; Scurlock, J.M.O.; Lindvall, E.; Christou, M. The Development and Current Status of Perennial Rhizomatous Grasses as Energy Crops in the US and Europe. Biomass Bioenergy 2003, 25, 335-361. [CrossRef]

94. Panacea. Scientific Papers and Training Materials-Panacea. Summary Factsheet Miscanthus; Agricultural University of Athens: Athens, Greece, 2020; Available online: http://www.panacea-h2020.eu/wp-content/uploads/2019/10/SUMMARY-FACTSHEET_ miscanthusV2.pdf (accessed on 20 October 2021).

95. Paris, P.; Mareschi, L.; Sabatti, M.; Pisanelli, A.; Ecosse, A.; Nardin, F.; Scarascia-Mugnozza, G. Comparing Hybrid Populus Clones for SRF across Northern Italy after Two Biennial Rotations: Survival, Growth and Yield. Biomass Bioenergy 2011, 35, 1524-1532. [CrossRef]

96. Navarro, A.; Facciotto, G.; Campi, P.; Mastrorilli, M. Physiological Adaptations of Five Poplar Genotypes Grown under SRC in the Semi-Arid Mediterranean Environment. Trees 2014, 28, 983-994. [CrossRef]

97. Fernández, M.J.; Barro, R.; Pérez, J.; Losada, J.; Ciria, P. Influence of the Agricultural Management Practices on the Yield and Quality of Poplar Biomass (a 9-Year Study). Biomass Bioenergy 2016, 93, 87-96. [CrossRef]

98. Stolarski, M.J.; Krzyżaniak, M.; Szczukowski, S.; Tworkowski, J.; Załuski, D.; Bieniek, A.; Gołaszewski, J. Effect of Increased Soil Fertility on the Yield and Energy Value of Short-Rotation Woody Crops. Bioenergy Res. 2015, 8, 1136-1147. [CrossRef]

99. Stolarski, M.J.; Krzyżaniak, M.; Tworkowski, J.; Szczukowski, S.; Niksa, D. Analysis of the Energy Efficiency of Short Rotation Woody Crops Biomass as Affected by Different Methods of Soil Enrichment. Energy 2016, 113, 748-761. [CrossRef]

100. Navarro, A.; Portillo-Estrada, M.; Arriga, N.; Vanbeveren, S.P.P.; Ceulemans, R. Genotypic Variation in Transpiration of Coppiced Poplar during the Third Rotation of a Short-Rotation Bio-Energy Culture. GCB Bioenergy 2018, 10, 592-607. [CrossRef]

101. Verlinden, M.S.; Broeckx, L.S.; Ceulemans, R. First vs. Second Rotation of a Poplar Short Rotation Coppice: Above-Ground Biomass Productivity and Shoot Dynamics. Biomass Bioenergy 2015, 73, 174-185. [CrossRef] 
102. Tilvikiene, V.; Kadziuliene, Z.; Dabkevicius, Z.; Venslauskas, K.; Navickas, K. Feasibility of Tall Fescue, Cocksfoot and Reed Canary Grass for Anaerobic Digestion: Analysis of Productivity and Energy Potential. Ind. Crop. Prod. 2016, 84, 87-96. [CrossRef]

103. Ust'ak, S.; Šinko, J.; Muňoz, J. Reed Canary Grass (Phalaris arundinacea L.) as a Promising Energy Crop. J. Cent. Eur. Agric. 2019, 20, 1143-1168. [CrossRef]

104. Strašil, Z. Evaluation of Reed Canary Grass (Phalaris arundinacea L.) Grown for Energy Use. Res. Agr. Eng. 2012, 58, 119-130. [CrossRef]

105. Cherney, J.H.; Ketterings, Q.M.; Davis, M.; Cherney, D.J.R.; Paddock, K.M. Management of Warm- and Cool-Season Grasses for Biomass on Marginal Lands: I. Yield and Soil Fertility Status. Bioenergy Res. 2017, 10, 959-968. [CrossRef]

106. Meehan, P.; Burke, B.; Doyle, D.; Barth, S.; Finnan, J. Exploring the Potential of Grass Feedstock from Marginal Land in Ireland: Does Marginal Mean Lower Yield? Biomass Bioenergy 2017, 107, 361-369. [CrossRef]

107. Carter, J.E.; Jokela, W.E.; Bosworth, S.C. Grass Forage Response to Broadcast or Surface-Banded Liquid Dairy Manure and Nitrogen Fertilizer. Agron. J. 2010, 102, 1123-1131. [CrossRef]

108. Jensen, E.F.; Casler, M.D.; Farrar, K.; Finnan, J.M.; Lord, R.; Palmborg, C.; Valentine, J.; Donnison, I.S. Reed Canary Grass: From Production to End Use. In Perennial Grasses for Bioenergy and Bioproducts; Alexopoulou, E., Ed.; Academic Press: Cambridge, MA, USA, 2018; ISBN 978-0-12-812900-5.

109. Reinhardt, J. Einfluss von organischen Säuren auf die Bioverfügbarkeit von Germanium im Pflanze-Boden System. Bachelor Thesis, Technical University of Freiberg, Germany, 2016.

110. Wiche, O.; Tischler, D.; Fauser, C.; Lodemann, J.; Heilmeier, H. Effects of Citric Acid and the Siderophore Desferrioxamine B (DFO-B) on the Mobility of Germanium and Rare Earth Elements in Soil and Uptake in Phalaris arundinacea. Int. J. Phytoremediation 2017, 19, 746-754. [CrossRef]

111. Panacea. Scientific Papers and Training Materials-Panacea. Summary Factsheet Sorghum; Agricultural University of Athens: Athens, Greece, 2020; Available online: http://www.panacea-h2020.eu/wp-content/uploads/2019/10/SUMMARY-FACTSHEET_ sorgho.pdf (accessed on 20 October 2021).

112. Barbanti, L.; Grandi, S.; Vecchi, A.; Venturi, G. Sweet and Fibre Sorghum (Sorghum Bicolor (L.) Moench), Energy Crops in the Frame of Environmental Protection from Excessive Nitrogen Loads. Eur. J. Agron. 2006, 25, 30-39. [CrossRef]

113. Diallo, B.; Li, M.; Tang, C.; Ameen, A.; Zhang, W.; Xie, G.H. Biomass Yield, Chemical Composition and Theoretical Ethanol Yield for Different Genotypes of Energy Sorghum Cultivated on Marginal Land in China. Ind. Crop. Prod. 2019, 137, 221-230. [CrossRef]

114. Fu, H.M.; Meng, F.Y.; Molatudi, R.L.; Zhang, B.G. Sorghum and Switchgrass as Biofuel Feedstocks on Marginal Lands in Northern China. Bioenergy Res. 2016, 9, 633-642. [CrossRef]

115. Cotton, J.; Burow, G.; Acosta-Martinez, V.; Moore-Kucera, J. Biomass and Cellulosic Ethanol Production of Forage Sorghum Under Limited Water Conditions. Bioenergy Res. 2013, 6, 711-718. [CrossRef]

116. Oikawa, P.Y.; Jenerette, G.D.; Grantz, D.A. Offsetting High Water Demands with High Productivity: Sorghum as a Biofuel Crop in a High Irradiance Arid Ecosystem. GCB Bioenergy 2015, 7, 974-983. [CrossRef]

117. Smith, G.A.; Buxton, D.R. Temperate Zone Sweet Sorghumethanol Production Potential. Bioresour. Technol. 1993, 43, 71-75. [CrossRef]

118. Wiedenfeld, R.P. Nutrient Requirements and Use Efficiency by Sweet Sorghum. Energy Agric. 1984, 3, 49-59. [CrossRef]

119. Zegada-Lizarazu, W.; Monti, A. Are We Ready to Cultivate Sweet Sorghum as a Bioenergy Feedstock? A Review on Field Management Practices. Biomass Bioenergy 2012, 40, 1-12. [CrossRef]

120. Panoutsou, C.; Singh, A. Training Materials for Agronomists and Students; Imperial College: London, UK, 2019.

121. Zeller, F.J. Sorghum (Sorghum Bicolor L. Moench): Utilization, Genetics, Breeding. Bodenkultur 2000, 51, 71-85.

122. Parrish, D.J.; Fike, J.H. The Biology and Agronomy of Switchgrass for Biofuels. Crit. Rev. Plant Sci. 2005, 24, 423-459. [CrossRef]

123. Panacea. Scientific Papers and Training Materials-Panacea. Summary Factsheet Switchgrass; Agricultural University of Athens: Athens, Greece, 2020; Available online: http://www.panacea-h2020.eu/wp-content/uploads/2019/10/SUMMARY-FACTSHEET_ switchgrass.pdf (accessed on 20 October 2021).

124. Ameen, A.; Tang, C.; Han, L.; Xie, G.H. Short-Term Response of Switchgrass to Nitrogen, Phosphorus, and Potassium on Semiarid Sandy Wasteland Managed for Biofuel Feedstock. Bioenergy Res. 2018, 11, 228-238. [CrossRef]

125. Sawyer, A.; Rosen, C.; Lamb, J.; Sheaffer, C. Nitrogen and Harvest Management Effects on Switchgrass and Mixed Perennial Biomass Production. Agron. J. 2018, 110, 1260-1273. [CrossRef]

126. Porensky, L.M.; Davison, J.; Leger, E.A.; Miller, W.W.; Goergen, E.M.; Espeland, E.K.; Carroll-Moore, E.M. Grasses for Biofuels: A Low Water-Use Alternative for Cold Desert Agriculture? Biomass Bioenergy 2014, 66, 133-142. [CrossRef]

127. Krzyżaniak, M.; Stolarski, M.J.; Szczukowski, S.; Tworkowski, J.; Bieniek, A.; Mleczek, M. Willow Biomass Obtained from Different Soils as a Feedstock for Energy. Ind. Crop. Prod. 2015, 75, 114-121. [CrossRef]

128. Labrecque, M.; Teodorescu, T.I. High Biomass Yield Achieved by Salix Clones in SRIC Following Two 3-Year Coppice Rotations on Abandoned Farmland in Southern Quebec, Canada. Biomass Bioenergy 2003, 25, 135-146. [CrossRef]

129. Amichev, B.Y.; Hangs, R.D.; Bélanger, N.; Volk, T.A.; Vujanovic, V.; Schoenau, J.J.; van Rees, K.C.J. First-Rotation Yields of 30 Short-Rotation Willow Cultivars in Central Saskatchewan, Canada. Bioenergy Res. 2015, 8, 292-306. [CrossRef]

130. Amichev, B.Y.; Volk, T.A.; Hangs, R.D.; Bélanger, N.; Vujanovic, V.; van Rees, K.C.J. Growth, Survival, and Yields of 30 ShortRotation Willow Cultivars on the Canadian Prairies: 2nd Rotation Implications. New For. 2018, 49, 649-665. [CrossRef] 
131. Lafleur, B.; Lalonde, O.; Labrecque, M. First-Rotation Performance of Five Short-Rotation Willow Cultivars on Different Soil Types and Along a Large Climate Gradient. Bioenergy Res. 2017, 10, 158-166. [CrossRef]

132. Larsen, S.U.; Jørgensen, U.; Lærke, P.E. Willow Yield Is Highly Dependent on Clone and Site. Bioenergy Res. 2014, 7, 1280-1292. [CrossRef]

133. Pray, T.; Guidi Nissim, W.; St-Arnaud, M.; Labrecque, M. Investigating the Effect of a Mixed Mycorrhizal Inoculum on the Productivity of Biomass Plantation Willows Grown on Marginal Farm Land. Forests 2018, 9, 185. [CrossRef]

134. Pari, L.; Scarfone, A. Inventory on Available Harvesting Technology for Industrial Crops on Marginal Lands; CREA: Rome, Italy, 2019. [CrossRef]

135. Scordia, D.; Cosentino, S.L. Perennial Energy Grasses: Resilient Crops in a Changing European Agriculture. Agriculture 2019, 9, 169. [CrossRef]

136. Stützel, H.; Brüggemann, N.; Inzé, D. The Future of Field Trials in Europe: Establishing a Network Beyond Boundaries. Trends Plant Sci. 2016, 21, 92-95. [CrossRef]

137. Boers, N. Observation-Based Early-Warning Signals for a Collapse of the Atlantic Meridional Overturning Circulation. Nat. Clim. Chang. 2021, 11, 680-688. [CrossRef]

138. Teuling, A.J. A Hot Future for European Droughts. Nat. Clim. Chang. 2018, 8, 364. [CrossRef]

139. Winkler, K.; Fuchs, R.; Rounsevell, M.; Herold, M. Global Land Use Changes Are Four Times Greater than Previously Estimated. Nat. Commun. 2021, 12, 2501. [CrossRef]

140. Reinhardt, J.; Hilgert, P.; von Cossel, M. Biomass Yield of Selected Herbaceous and Woody Industrial Crops across Marginal Agricultural Sites with Shallow Soil. Agronomy 2021, 11, 1296. [CrossRef]

141. Reinhardt, J.; Hilgert, P.; Von Cossel, M. Yield Performance of Dedicated Industrial Crops on Low-Temperature Characterized Marginal Agricultural Land in Europe-A Review. Biofuels Bioprod. Biorefining. (in press). [CrossRef] 